\title{
Immunology Taught by Human Genetics
}

\author{
Jean-Laurent Casanova, ${ }^{1,2,3}$ Laurent Abel, ${ }^{1,2,3}$ and Lluis Quintana-Murci ${ }^{4,5}$ \\ ${ }^{1}$ St. Giles Laboratory of Human Genetics of Infectious Diseases, Rockefeller Branch, \\ The Rockefeller University, New York, New York 10065 \\ ${ }^{2}$ Laboratory of Human Genetics of Infectious Diseases, Necker Branch, INSERM U980, \\ Necker Hospital for Sick Children, Paris 75015, France \\ ${ }^{3}$ Paris Descartes University, Imagine Institute, Necker Hospital, Paris 75015, France \\ ${ }^{4}$ Unit of Human Evolutionary Genetics, Pasteur Institute, Paris 75015, France \\ ${ }^{5}$ CNRS URA 3012, Paris 75015, France \\ Correspondence: casanova@rockefeller.edu
}

\begin{abstract}
Human genetic studies are rarely conducted for immunological purposes. Instead, they are typically driven by medical and evolutionary goals, such as understanding the predisposition or resistance to infectious or inflammatory diseases, the pathogenesis of such diseases, and human evolution in the context of the long-standing relationships between humans and their commensal and environmental microbes. However, the dissection of these experiments of Nature has also led to major immunological advances. In this review, we draw on some of the immunological lessons learned in the three branches of human molecular genetics most relevant to immunology: clinical genetics, epidemiological genetics, and evolutionary genetics. We argue that human genetics has become a new frontier not only for timely studies of specific features of human immunity, but also for defining general principles of immunity. These studies teach us about immunity as it occurs under "natural" conditions, through the transition from the almost complete wilderness that existed worldwide until about a century ago to the current unevenly distributed medically shaped environment. Hygiene, vaccines, antibiotics, and surgery have considerably decreased the burden of infection, but these interventions have been available only recently, so have yet to have a major impact on patterns of genomic diversity, making it possible to carry out unbiased evolutionary studies at the population level. Clinical genetic studies of childhood phenotypes have not been blurred by modern medicine either. Instead, medical advances have actually facilitated such studies, by making it possible for children with life-threatening infections to survive. In addition, the prevention and treatment of infectious diseases have increased life expectancy at birth from $\sim 20 \mathrm{yr}$ to $\sim 80 \mathrm{yr}$, providing unique opportunities to study the genetic basis of immunological phenomena against which there is no natural counterselection, such as reactivation and secondary infectious diseases and breakdown of self-tolerance manifesting as autoimmunity, in populations of adult and aging patients. Recently developed deep sequencing and stem cell technologies are of unprecedented power, and their application to human genetics is opening up exciting and timely possibilities for young immunologists seeking uncharted waters to explore.
\end{abstract}

Research in humans is increasingly contributing to immunology, not only by defining human-specific features of immunity, but also by revealing general principles of immunity. There are many difficulties inherent to studies of humans, including the great ethical and technical difficulties of experimental approaches, and the tremendous level of inter-individual variability. These obstacles account for the systematic development of experimental approaches in inbred animals from the early 19th century onward. For a long time, human genetics in immunology (i.e., immunogenetics) was almost synonymous with "HLA and transplantation" and "HLA and disease." Major discoveries were made in this area, such as the strong associations of HLA-B27 with spondylarthropathies and of HLA-DQ8 with type 1 diabetes (T1D). However, a few notable discoveries were made outside the realm of HLA, such as the protective role of the sickle-cell trait $(\mathrm{HbS})$ in severe malaria. These and other genetic epidemiological studies have been extended, facilitating the dissection of the seemingly complex basis of phenotypes at the popu- lation level (i.e., phenotypes common to large number of patients). The impact of these findings was perhaps more medical than immunological. In the 1970s and the 1980s, when these seminal discoveries on HLA were made, only a few investigators would have predicted that human genetics would soon contribute to immunology in other more spectacular ways.

During the last 30 years, with the emergence of recombinant DNA and molecular genetics, we have witnessed continued and extraordinary progress in the tools of human genetics. This progress has accelerated further during the last 15 years, from Sanger sequencing of the first human genome to the next-generation sequencing (NGS) of countless whole exomes and genomes. These and other achievements, both experimental and statistical, have transformed the genetic variability and phenotypic heterogeneity of human populations from a liability into an asset. They have made it possible to exploit observations of human phenotypes under natural conditions, in natura, with an understanding of their germline genetic basis in 
each individual. Primary immunodeficiencies (i.e., single-gene inborn errors of immunity) have made a particularly important contribution in this respect, and studies in this field are increasing adding to immunological knowledge. More recently, an older branch of genetics - human evolutionary and population genetics - has reemerged as a powerful molecular approach, following the generation of gigantic data sets cataloging human genetic variation in "healthy" (but nevertheless mortal) individuals (The International HapMap Project, The 1000 Genomes Project, etc.). Evolutionary genetic studies analyze the extent of naturally occurring variations at the level of human populations, transforming the disadvantages of interindividual and interpopulation variation into an advantage, without the need for phenotypic selection.

Clearly, the times when human immunogenetics was synonymous with HLA are long gone. Modern human molecular genetic approaches can be divided into three complementary and overlapping approaches: clinical genetics, epidemiological genetics, and evolutionary genetics. We review here the concepts and methods of these three branches of human genetics, discussing the ways in which they are likely to increase our understanding of immunology in the future. According to Krogh's principle, there is often a "best" species in which to tackle a specific scientific problem experimentally (Krogh 1929; Krebs 1975); implicit within this notion is the assumption that an experimental solution to the problem is required, as suggested by Claude Bernard (1865). However, we can also view "experiments of Nature" in humans as an alternative and complementary way of approaching a wide range of biological problems (McQuarrie 1944), including immunological problems in particular (Good 1991). Now is the ideal time to study such natural experiments, as hygiene, vaccines, antibiotics, surgery, and other features of modern medicine have not yet been around long enough to modify the distribution of genotypes at the scale of human populations. We argue here that human genetics has thrust immunology into a new dimension, and that such studies are complementary to experimental studies in the mouse or even more distant animal models (Drosophila, lamprey, zebrafish, etc.). Inspired by insightful papers on what studies of viruses (Zinkernagel 1996), bacteria (Vance 2010), humans (Davis 2012) and even Darwin (Phillips 2002) have taught us about immunology, we will focus on the lessons to be learnt about immunology from human genetics. Owing to space limitations, we will limit ourselves here to genetic studies of infectious and inflammatory diseases.

\section{CLINICAL GENETIC STUDIES}

\section{General Concepts and Methods}

Genetic studies of primary immunodeficiencies (i.e., single-gene inborn errors of immunity) have had a tremendous impact in the field of immunology (Conley et al. 2011; Casanova et al. 2013). These patient-based studies typically aim to investigate the pathogenesis of a relatively rare, specific textbook medical condition, a small group of patients resembling each other but no textbook description, or even, in some cases, a single patient with a new clinical presentation (Al-Herz et al. 2011; Bousfiha et al. 2013a). These genetic defects have an impact on the population that is individually modest (although their collective impact is greater) (Bousfiha et al. 2013b), but their elucidation has major implications for immunology, as they can connect a morbid genotype to a clinical phenotype. Studies of this kind are the easiest for most immunologists working with animals to understand, as this branch of human genetics is the closest to their own field. Such studies aim to describe the disease-causing genotype, immunological mechanism, and clinical phenotype of patients with a monogenic defect, as in mutant mice discovered by forward genetics or created by reverse genetics approaches. We use the terms monogenic and single-gene defects interchangeably throughout this review. We do not restrict the term "Mendelian" to monogenic defects, as this term implies full clinical penetrance, which is not observed in all cases. Penetrance is the proportion of individuals carrying a given genotype that actually express a disease phenotype. Expressivity is the variability of the phenotype (e.g., in terms of severity) considered among the patients studied who carry a given genotype. An increasing number of single-gene inborn errors of immunity have been described since the $1950 \mathrm{~s}$ (Casanova and Abel 2007; Pessach et al. 2009). The first such defects to be described were autosomal recessive (AR) or X-linked recessive (XR), but an increasing number of autosomal-dominant (AD) traits have recently been reported (Al-Herz et al. 2011; Bousfiha et al. 2013a). Only in very rare instances the defect is mitochondrial.

\section{Locus, Allelic, and Phenotypic Heterogeneity}

The mutant alleles in patients with inborn errors of immunity may be null (i.e., loss-of-function, sensu stricto) or hypomorphic (i.e., with residual activity). Interestingly, hypermorphic (i.e., gain-of-function) mutations have also recently been described (Devriendt et al. 2001; Courtois et al. 2003; Liu et al. 2011). The high level of allelic heterogeneity (i.e., diversity of mutant alleles at a given morbid locus, exerting diverse impacts) makes the investigation of human patients with mutations of a given gene particularly rich, due to this diversity (e.g., $R A G 1$ and $R A G 2$ mutations underlying different types of T-cell deficits, and STAT1 mutations underlying different types of infections, of different severity) (Buckley 2004; BoissonDupuis et al. 2012; Notarangelo 2013) (Table 1), whereas mutant mice tend to display uniform complete defects, particularly for gene knockout. Even knocked-in and ENU-mutated mice do not display the level of allelic diversity observed in humans. There are no conditional knockouts in humans, but some subtle mutations behave differently in different cell types, being null in some cell types but not in others (e.g., $C Y B B$ mutations affecting only macrophages in patients with Mendelian susceptibility to mycobacterial disease, MSMD) (Bustamante et al. 2011). Perhaps the greatest surprise of all is the unpredictable impact of AD traits, which may exert their effects 
Table 1. Four inborn errors of STAT1 immunity: an illustration of variable inheritance, allelic heterogeneity, variable expressivity, variable penetrance, and locus pleiotropy

\begin{tabular}{|c|c|c|c|}
\hline Functional impact & Inheritance & Immunological phenotypes & Clinical phenotypes \\
\hline Complete STAT1 defect & AR & $\begin{array}{l}\text { Abolished IFN- } \alpha / \beta,-\gamma,-\lambda, \text { IL-27 } \\
\text { responses }\end{array}$ & $\begin{array}{l}\text { Severe intracellular bacterial (mycobacteria, } \\
\text { salmonella) and viral diseases }\end{array}$ \\
\hline Partial STAT1 defect & AR & $\begin{array}{l}\text { Impaired IFN- } \alpha / \beta,-\gamma,-\lambda, \text { IL-27 } \\
\text { responses }\end{array}$ & Milder intracellular bacterial and viral diseases \\
\hline Partial STAT1 defect & $\mathrm{AD}$ & Selectively impaired IFN- $\gamma$ responses & Selective intracellular bacterial diseases (MSMD) \\
\hline Gain of STAT1 activity & $\mathrm{AD}$ & $\begin{array}{l}\text { Enhanced IFN- } \alpha / \beta,-\gamma,-\lambda, \text { IL-27 } \\
\text { responses }\end{array}$ & $\begin{array}{l}\text { CMC, other infections, autoimmunity, aneurysms, } \\
\text { carcinomas }\end{array}$ \\
\hline
\end{tabular}

There is allelic heterogeneity at the human STAT1 locus not only because there are multiple mutant morbid alleles but more importantly because they have different impacts: they can be gain-of-function (GOF) or loss-of-function (LOF), the latter including truly null and hypomorphic alleles. The known GOF alleles are gain of phosphorylation by lack of nuclear dephosphorylation. The STAT1 mutations actually define two modes of inheritance, with two types of AR defects and two types of AD defects. The AR defects are complete (two null alleles) or partial (at least one hypomorphic allele). The AD disorders confer gain (GOF alleles) or loss (LOF and dominant-negative alleles) of activity. In fact, the dominant-negative LOF alleles of STAT1 can be null or hypomorphic and can be further divided into at least three groups, depending on whether they affect the DNA-binding domain, the SH2 domain, or the phosphorylation of Tyr 701. The GOF alleles of STAT1 can also affect the coiled-coil domain or the DNA-binding domain. There is variable expressivity as for each of the four types of inborn errors, the clinical severity varies from patient to patient, possibly but not necessarily depending on the specific STAT1 genotype. There is even variable penetrance clinically overall: The clinical penetrance is apparently complete at an early age in patients with complete AR deficiency and AD gain of activity, whereas the disorder may be silent until adulthood and possibly for a lifetime for the partial defects (incomplete penetrance). Finally, the human STAT1 locus is pleiotropic because completely different infectious diseases are allelic at the STAT1 locus, each determined by a specific type of mutant allele (MSMD with dominant-negative alleles and CMC with GOF alleles). These disorders were recently reviewed (Boisson-Dupuis et al. 2012).

by haploinsufficiency (e.g., RPSA mutations underlying asplenia and TBK1 mutations underlying HSE) or by dominant-negative effects (e.g., STAT1 mutations underlying MSMD and other TBK1 mutations in herpes simplex encephalitis, HSE). The number of known AD inborn errors of immunity is increasing and constitutes an exciting trend in human studies. Heterozygous mutations may also have different effects on different pathways, being null for all pathways but associated with an AD phenotype in some pathways (e.g., STAT1 mutations affecting IFN- $\gamma$ but not IFN- $\alpha / \beta$ responses in MSMD patients) but not others. Negative dominance accounted for the first AD defects, but haploinsufficiency is increasingly documented, sometimes in the same pathway (e.g., IFNGR1 and IFNGR2 underlying MSMD) (Jouanguy et al. 1999; Kong et al. 2013). Both AR and AD disorders may result in partial defects, facilitating the observation of phenotypes not seen with embryonic lethal AR complete defects in mice or humans (e.g., TRAF3 in HSE and MCM4 in NK deficiency) (Perez de Diego et al. 2010; Gineau et al. 2012; Hughes et al. 2012). Finally, a particular gene may be subjected to both loss- and gain-of-function mutations (e.g., WASP mutations underlying Wiskott-Aldrich syndrome or neutropenia, and STAT1 mutations MSMD or chronic mucocutanous candidiasis, CMC). This complexity has not been observed in the mouse model. There is also considerable locus heterogeneity (i.e., diversity of mutant loci underlying a given disease phenotype), which can connect hitherto unrelated genes (e.g., agammaglobulinemia and MSMD) (Al-Muhsen and Casanova 2008; Conley et al. 2009). Conversely, there is also pleiotropy at many loci (i.e., apparently unrelated diseases being allelic at the same locus, possibly, but not necessarily, by the same mechanism), potentially connecting hitherto unrelated phenotypes (e.g., STAT1 heterozygous mutations underlying MSMD or CMC) (Boisson-Dupuis et al. 2012). Finally, it is worth stressing that the diversity of disease phenotypes known to be caused by inborn errors of immu- nity is steadily increasing. From infections, autoimmunity, allergy, and cancer, which were first recognized as being due to inborn errors of immunity in the 1950s and 1960s, the field has expanded to include phenotypes as diverse as hemophagocytosis, autoinflammation, alveolar proteinosis, and microangiopathies (Casanova and Abel 2007; Kavanagh et al. 2008; Masters et al. 2009; Pessach et al. 2009; Trapnell et al. 2009; Pachlopnik Schmid et al. 2010). There are probably many more relevant phenotypes to be discovered, as the clinical frontiers of this field are relentlessly advancing.

\section{The Discovery of New Genes}

So, from an immunological perspective, what should we consider to be the highlights of clinical genetics over the last three decades of gene cloning? First, immunological hypothesis-free, genome-wide (GW) approaches have led to the identification of completely new genes (i.e., previously unknown genes or genes with no known biological function). The cellular complementation of cellular phenotypes led to elucidation of the molecular genetic basis of HLA class II deficiency. This tour de force characterized the nature, diversity, and role of a set of proteins responsible for regulating the transcription of HLA class II loci (e.g., CIITA) (Reith et al. 1988; Krawczyk and Reith 2006). This high-risk approach was less fruitful than the much simpler GW linkage (GWL) approach, which has led to the identification of multiple new genes. The first example was the dissection of the gene controlling the phagocytic respiratory burst and mutated in X-linked chronic granulomatous disease, which was made possible by GWL (Royer-Pokora et al. 1986; Teahan et al. 1987). GWL is not unlike forward genetics in mice, which has generated a series of spectacular immunological discoveries (e.g., Nramp, Ly49 H, Tlr4, and Foxp3) (Cook et al. 2006; Beutler et al. 2007; Appleby and Ramsdell 2008; Scalzo and Yokoyama 2008; Vidal 
et al. 2008). Examples of human genes identified by GWL include ATM, BTK, WASP, ARTEMIS, and AIRE, to cite only some of the most interesting (Tsukada et al. 1993; Derry et al. 1994; Savitsky et al. 1995; Consortium, Finnish-German APECED 1997; Nagamine et al. 1997; Moshous et al. 2001). Some of these genetic defects identified molecules as involved in biological processes that had previously been characterized, such as VDJ recombination (e.g., Artemis) (Moshous et al. 2001). Others have revealed the involvement of completely new pathways. Perhaps the most far-reaching success was the discovery of the genetic basis of AR autoimmune polyendocrinopathy type I (APS-1) (Husebye and Anderson 2010) as mutations of AIRE. This led to major molecular advances in the field of T-cell tolerance. AIRE controls the thymic expression of peripheral antigens and has also been shown to control tolerance in the periphery (Anderson et al. 2002; Gardner et al. 2008). Patients with APS-1 display multiple autoimmune manifestations, including chronic mucocutaneous candidiasis that is caused, paradoxically, by autoantibodies against IL-17 cytokines (Kisand et al. 2010; Puel et al. 2010). The positional cloning of AIRE has opened up an entirely new field in immunology (Abramson et al. 2010). Needless to say, human GWL studies have also had important clinical implications.

\section{The Identification of New Functions for Known Genes}

A different, but related situation is the discovery of a new function for a known gene (i.e., a gene to which a different biological function has already been attributed). This discovery may pertain to a novel immunological function or even to the first immunological function of the protein concerned. An example of the former is provided by IL2RG, which was initially identified as a component of the IL-2R. Mutations in children with XR severe combined immunodeficiency (SCID) lacking both T cells and NK cells implied an involvement in other pathways (Noguchi et al. 1993; Puck et al. 1993). Indeed, the lack of T-cell development was later explained by the lack of IL2RG-dependent IL-7 responses, with the identification of IL-7R deficiency in other SCID patients in whom NK cells were present (Puel et al. 1998). A more recent example is provided by mutations in X-linked MAGT1, encoding Magnesium transporter 1, which were surprisingly shown to confer an NK and a T-cell deficiency that results in Epstein-Barr virus (EBV)-driven diseases (Li et al. 2011; Chaigne-Delalande et al. 2013). Mutated individuals display low levels of free $\mathrm{Mg}^{2+}$ in their NK and T cells, which accounts for low NKG2D expression and poor control of EBV-infected cells. Strikingly, $\mathrm{Mg}^{2+}$ supplementation in vivo complemented the immunological and infectious phenotypes. Another recent example is ISG15, which has been shown to be mutated in patients with mycobacterial disease but normal resistance to viral illnesses (Bogunovic et al. 2012). The known biological and immunological function of ISG15 is as a ubiquitin-like molecule essential for ISGylation, an intracellular process that is dependent on IFN- $\alpha / \beta$ and contributes to antiviral immunity in mice (Bogunovic et al. 2013). The discovery that ISG15 is a secreted molecule that also functions as a potent IFN- $\gamma$ inducer was made by GWL and wholeexome sequencing (WES). A related example is the discovery that patients deprived of linear ubiquitination because of inherited HOIL1 deficiency display a combination of immunodeficiency, autoinflammation, and amylopectinosis (Boisson et al. 2012). A striking example of the discovery of a first immunological function for a known gene is provided by the recent WES-based discovery of heterozygous mutations of the gene encoding the ribosomal protein RPSA in patients with isolated congenital asplenia (ICA) (Bolze et al. 2013). RPSA was not known to play a role in the development or function of the immune system. Over half the patients with ICA carry RPSA heterozygous coding mutations and the mechanism underlying the disease involves haploinsufficiency. This is interesting, because RPSA and ribosomes appear to play a specific role in the translation of certain mRNAs controlling spleen development. Another example is provided by the discovery of biallelic MCM4 mutations in patients with a complex phenotype including a selective NK deficiency in the hematopoietic lineage (Gineau et al. 2012; Hughes et al. 2012). The minichromosome maintenance (MCM) complex was not known to be essential for the final steps of CD56 $6^{\text {bright }}$ cell maturation to generate CD56 ${ }^{\text {dim }}$ human NK cells.

\section{The Discovery of Essential Functions of Known Genes}

Most monogenic immunodeficiencies were discovered through candidate gene approaches, making use of the known immunological function of various genes. The discovery of humans carrying mutations in these genes was made possible by prior description of the functions of these genes in mice, often by gene targeting but occasionally by forward genetics, or even in humans. In some cases, the candidate gene approach was sufficient, as for the demonstration that IL-7R deficiency is a cause of SCID. In other cases, the candidate gene approach was not used in isolation, instead being combined with GWL, WES, or both. For example, IFN- $\gamma$ R1 deficiency was discovered in patients with MSMD and UNC-93B deficiency was detected in patients with HSE by the combination of GWL with a candidate gene approach (Jouanguy et al. 1996; Newport et al. 1996; Casrouge et al. 2006). In such situations, the morbid gene is chosen for mechanistic studies from a small set of genes selected on the basis of linkage or sequencing. In rare instances, the candidate gene approach is almost nonexistent, as GWL and WES identify a single mutated gene, as illustrated by the discovery of OX40 deficiency in patients with Kaposi sarcoma (Byun et al. 2013). Interestingly, a key lesson to be learnt from these studies is that the human disease phenotype often overlaps, but does not exactly match the phenotype observed in the mouse model. These phenotypic differences are particularly marked when the infectious and autoimmune phenotypes are considered, as seen with inborn errors of IFN- $\gamma$, IL-17, TLR3, and TIR immunity (Casa- 
nova and Abel 2002; Casrouge et al. 2006; Ku et al. 2007; Zhang et al. 2007, 2013; von Bernuth et al. 2008; Casanova et al. 2011; Liu et al. 2011; Puel et al. 2011, 2012; Bogunovic et al. 2012). In particular, the infectious phenotypes of humans tend to be much narrower than those observed in mice. Surprisingly, a number of severe infections striking otherwise healthy children were shown to be due to singlegene inborn errors of immunity (Casanova and Abel 2005, 2013; Alcais et al. 2010). These and other studies also revealed infectious phenotypes not predicted by the mouse model. For example, the discovery that human IL-21 is essential for protective immunity against Cryptosporidium parvum in the liver was surprising (Kotlarz et al. 2013). Likewise, the autoimmune phenotypes of mice and humans do not entirely overlap for Fas, Foxp3, and AIRE deficiencies (Notarangelo et al. 2006; Cheng and Anderson 2012). The development and function of leukocyte subsets may also differ between mice and humans, albeit to a lesser extent and less frequently, as seen, for example, with BTK and IL2RG deficiencies (Buckley 2004; Conley et al. 2009). In any case, human genes display greater redundancy, for both host defense and self-tolerance, than mouse genes, accounting for the narrow infectious or autoimmune phenotype often seen, contrasting with the broader corresponding mouse phenotype. We have explained in detail elsewhere why we believe this is the case, with both differences between species and differences between experimental and natural phenotypes (Casanova and Abel 2004). One issue of key interest in human genetics is the description of immunity in natura, in a natural ecosystem governed by natural selection (Casanova and Abel 2007; Quintana-Murci et al. 2007). Finally, it has gradually become apparent that many single-gene inborn errors of immunity do not display full clinical penetrance, particulary, but not exclusively, AD disorders (e.g., IL12RB1 and TLR3) (Fieschi et al. 2003; Zhang et al. 2007; de Beaucoudrey et al. 2010). The search for the germline, somatic, or environmental determinism of health or disease in genetically affected individuals is a major goal in the field, which will also have an immunological impact.

\section{GENETIC EPIDEMIOLOGICAL STUDIES}

\section{General Concepts and Methods}

Genetic epidemiology involves population-based studies that combine epidemiological and genetic information to identify gene variants with a detectable influence on phenotypes at the population level (Khoury et al. 1993; Alcais and Abel 2004). Before genetic markers became available, many methods were developed for assessing the familial aggregation of a trait. These methods included twin studies (Khoury et al. 1993), which provided strong evidence for the role of genetic factors in both inflammatory diseases, including but not limited to autoimmune diseases (Cooper et al. 1999), and infectious diseases (Alcais and Abel 2004). The most formalized approach in this context is complex segregation analysis, a statistical method in which the familial distribution of a given phenotype results from the combined effects of a "major lo- cus," a polygenic component and environmental factors (Khoury et al. 1993; Alcais and Abel 2004; Alcais et al. 2009a). A major gene differs from a "Mendelian" effect in displaying incomplete penetrance and its phenotypic expression may be influenced by the environment and other genes (including germline and somatic variants, and both genetic and epigenetic influences) (Alcais et al. 2009a,b). The existence of major genes for various inflammatory (Cooper et al. 1999) and infectious (Alcais et al. 2009a) phenotypes was first suspected in the $1970 \mathrm{~s}$. The advent of genetic markers led to the development of the two pillar methods of genetic epidemiology, linkage and association studies, making it possible to identify major genes, as detailed below. Both linkage and association studies can be conducted according to two classical strategies (Casanova and Abel 2004; Alcais et al. 2009a): (1) a "candidategene" approach, with the a priori selection of one or a limited number of genes/variants to be tested, based on knowledge obtained from experimental or human studies; (2) a "GW" approach, in which the whole genome is investigated, to generate new hypotheses. All these studies are based on statistical tests and stringent criteria, including replication in independent studies, must be met for the results to be considered convincing. Evidence for a causal role of a polymorphism may also be provided by functional studies, which can be challenging, as the biological impact of the polymorphism may be subtle.

\section{Linkage Studies}

Linkage studies are used to search for chromosomal regions that segregate in a nonrandom manner with the phenotype of interest within families (Khoury et al. 1993; Alcais and Abel 2004). Initially, the regions identified were limited to those for which markers were available, such as the HLA region in particular. The development of GWL screens in the 1990s extended the use of the major gene concept to loci identified in this context (Alcais et al. 2009a,b). HLA-linked major loci were identified by these approaches in a number of inflammatory disorders (Forabosco et al. 2009), such as T1D (Concannon et al. 2005), multiple sclerosis (MS) (Sawcer et al. 2005), and ankylosing spondylitis (AS) (Zhang et al. 2004). Several non-HLA major loci have also been mapped in GWL screens (Goris and Liston 2012). Unfortunately, in contrast to the situation for more penetrant monogenic diseases, fine mapping of the genes of interest cannot be achieved by linkage alone. The next step is investigating the role of variants located within the identified region in comprehensive association studies. One of the most remarkable instances of the identification of a nonHLA locus in an immunological disorder was the discovery of NOD2/CARD15 variants in patients with Crohn's disease $(C D)$, within the chromosome 16 region (Hugot et al. 2001; Ogura et al. 2001) previously identified by GWL analysis (Hugot et al. 1996). This positional cloning strategy also led to the identification of variants at two major loci mapped in a GWL study on leprosy (Mira et al. 2003). The first of these variants, on chromosome $6 \mathrm{q} 25$, concerned the regulatory region shared by $P A R K 2$, a 
gene encoding an E3-ubiquitin ligase called Parkin, and PACRG (Parkin coregulated gene) (Mira et al. 2004). The second, on chromosome $6 \mathrm{p} 21$, was a single functional polymorphism of the lymphotoxin- $\alpha$ (LTA) gene (Alcais et al. 2007). More recently, $T O X$ variants have been shown to be associated with pulmonary tuberculosis (TB) (Grant et al.2013), following the identification of a major locus on chromosome 8q12 (Baghdadi et al. 2006). The association observed in these studies was much stronger in patients who developed early-onset leprosy or pulmonary TB, consistent with the general concept that a younger age at onset of the disease reflects a stronger individual genetic effect (Alcais et al. 2010; Casanova and Abel 2013).

\section{Candidate Gene Association Studies}

Association studies aim to assess the contribution of genetic variants to the disease studied by comparing the distribution of these variants between affected (cases) and unaffected (controls) subjects (Khoury et al. 1993; Alcais and Abel 2004). Family-based designs can also be used for association studies (Laird and Lange 2006). Until the advent of high-throughput genotyping, such studies investigated a limited number of variants of candidate genes. The first and, probably, the most remarkable association was that identified by Anthony Allison, who discovered in the early $1950 \mathrm{~s}$ that $\mathrm{HbS}$ was protective against severe forms of $P$. falciparum malaria (Allison 1954). However, the candidate genes most frequently studied in inflammatory and infectious diseases since the 1970s have been those of the HLA region. Consistent with the linkage results, the most interesting findings have been obtained for inflammatory disorders, with a number of impressive associations (Thorsby and Lie 2005; Cho and Gregersen 2011; Goris and Liston 2012). Interestingly, most HLA associations seem to be specific to a given disease, and in many diseases the presence of a given HLA molecule is almost necessary, but not sufficient for disease. One of the most emblematic examples is the association of HLA-B27 with AS. Almost all AS patients carry this HLA antigen, but most HLA-B27 subjects do not develop AS (Uchanska-Ziegler et al. 2012). HLA genes appear to play a much less striking role in infectious diseases, as most of the many associations reported have not been confirmed (Martin and Carrington 2005; Blackwell et al. 2009). There may be a number of reasons for this, such as considerable heterogeneity (e.g., in terms of ethnic origin, phenotype definition, HLA typing, microbial strains) of the samples tested for a given disease. The most consistent results obtained with HLA variants have been those for leprosy (Zhang et al. 2009a) and, particularly, for HIV infection (Goulder and Watkins 2008; Leslie et al. 2010), with some HLA class I alleles being associated with relatively successful control of viral replication and slow disease progression (Migueles et al. 2000; Kiepiela et al. 2004), and others being associated with relatively ineffective control of viral replication and rapid disease progression (Carrington et al. 1999; Kiepiela et al. 2004). Finally, a recent study reported that autoantibodies against IFN- $\gamma$ conferring a predisposition to mycobacterial infec- tions and mimicking MSMD (Puel and Casanova 2013) are strongly associated with two linked HLA class II alleles (Chi et al. 2013).

\section{Genome-Wide Association Studies}

A breakthrough occurred in the mid-2000 with the advent of GW association studies (GWASs), following the development of high-throughput genotyping. The first spectacular finding obtained in a GWAS was the identification, in 2005, of complement factor $\mathrm{H}$ polymorphisms in patients with age-related macular degeneration (Klein et al. 2005) providing new insight into the immune-related pathogenesis of this disease (Ambati et al. 2013). The same result was however obtained following a linkage approach (Edwards et al. 2005; Haines et al. 2005). GWAS also confirmed that the HLA region contained the common variants with the greatest impact on inflammatory disorders, and identified more than 250 additional loci associated with one or more of these diseases (Cho and Gregersen 2011; Visscher et al. 2012). A number of the non-HLA loci have been implicated in multiple diseases, defining common pathways and suggesting similar underlying mechanisms for these diseases (Cho and Gregersen 2011; Cotsapas et al. 2011; Goris and Liston 2012; Voight and Cotsapas 2012). For example, 70\% of the 163 loci for which involvement in CD and ulcerative colitis (UC) has been confirmed (Jostins et al. 2012) have also been implicated in other inflammatory diseases (such as AS and psoriasis in particular), and there is also an interesting overlap with loci conferring susceptibility to mycobacterial infection. These 163 loci include five MSMDrelated loci (IL12B, IFNGR2, STAT1, IRF8, TYK2), and seven of the eight loci identified in the leprosy GWAS (including NOD2/CARD15) (Zhang et al. 2009b, 2011) have also been implicated in CD and UC (Jostins et al. 2012). The effects of CD/UC and mycobacterial risk alleles on gene function and expression include effects operating in opposite (e.g., NOD2/CARD15) and similar (e.g., IFNGR2) directions (Jostins et al. 2012). GWASs have identified fewer loci involved in infectious diseases. Some of the findings of these studies have confirmed previously reported associations with HLA variants in leprosy (Zhang et al. 2009b), and chronic viral infections (Fellay et al. 2007; Dalmasso et al. 2008; Kamatani et al. 2009; Pereyra et al. 2010). However, the most remarkable achievement of GWAS in infectious diseases has been the identification of $I L 28 \mathrm{~B}$ variants associated with the clearance of HCV either in response to treatment (Ge et al. 2009; Suppiah et al. 2009; Tanaka et al. 2009) or spontaneously (Thomas et al. 2009; Duggal et al. 2013). The molecular mechanisms underlying this association remained elusive until the recent identification of a new dinucleotide variant (TT vs. $\Delta \mathrm{G}$ ) in the $I L 28 B$ region (Bibert et al. 2013; Prokunina-Olsson et al. 2013). The $\Delta \mathrm{G}$ allele associated with poorer clearance of the virus is a frameshift variant that apparently generates a new gene, IFNL4, encoding a putative IFN- $\lambda 4$ protein (ProkuninaOlsson 2013). The mechanisms by which IFN- $\lambda 4$ may impair HCV clearance remain to be deciphered. 


\section{The Search for Missing Heritability}

GWAS has made it possible to identify common variants with modest effects at hundreds of loci, for a number of common diseases, including inflammatory and autoimmune diseases (Visscher et al. 2012). However, even at its most successful, such as when applied to CD and to inflammatory diseases in general, the loci identified by this approach account for only a small proportion of the variance of disease risk (e.g., 13.6.\% in CD [Casanova and Abel 2009; Smith et al. 2009; Jostins et al. 2012]). This has led to the concept of "missing heritability" (Manolio et al. 2009) and to the development of several non-mutually exclusive hypotheses that might account for this phenomenon (Table 2). One of these explanations, the existence of rare disease-causing variants, is appealing for at least two reasons: (1) conceptually, as rare variants bridge the gap between Mendelian and complex inheritance and largely correspond to the major gene notion (Alcais et al. 2009a, 2010), and (2) experimentally, as these variants can now be tested by NGS (Cirulli and Goldstein 2010). One recent study reported a negligible impact of rare variants located in the exons of 25 risk genes previously identified by GWASs in $\sim 25,000$ patients with six autoimmune and/or inflammatory diseases (Hunt et al. 2013). A more successful use of this approach resulted in the demonstration that the DCTN4 gene influenced Pseudomonas aeruginosa infection in patients with cystic fibrosis (Emond et al. 2012). This discovery was based on WES in patients with "extreme phenotypes" (43 patients with the earliest onset of infection vs. 48 patients with the latest onset of infection). The search for missing heritability is, undoubtedly, a major challenge in this field.

Table 2. A selection of genetic hypotheses possibly accounting for missing heritability in inflammatory and infectious diseases

\begin{tabular}{|c|c|}
\hline Masked genetic effect & Methods of investigation \\
\hline $\begin{array}{l}\text { Causal common variants not } \\
\text { identified }\end{array}$ & $\begin{array}{l}\text { Dense targeted sequencing of } \\
\text { disease-associated regions and } \\
\text { functional studies }\end{array}$ \\
\hline $\begin{array}{l}\text { Other common variants with } \\
\text { weaker effect not identified }\end{array}$ & $\begin{array}{l}\text { Increase population sample size } \\
\text { and conduct large meta- } \\
\text { analyses }\end{array}$ \\
\hline $\begin{array}{l}\text { Rare variants with stronger } \\
\text { effect not identified }\end{array}$ & $\begin{array}{l}\text { Next-generation sequencing } \\
\text { focusing on specific kindreds } \\
\text { (multiplex) and phenotypes } \\
\text { (extreme). }\end{array}$ \\
\hline $\begin{array}{l}\text { "Structural" variants not } \\
\text { identified (e.g., copy } \\
\text { number variants) }\end{array}$ & $\begin{array}{l}\text { Specific analysis of high- } \\
\text { throughput genotyping and } \\
\text { sequencing data }\end{array}$ \\
\hline $\begin{array}{l}\text { Gene } \times \text { gene interaction and } \\
\text { epistasis }\end{array}$ & $\begin{array}{l}\text { Development of specific } \\
\text { methods of analysis }\end{array}$ \\
\hline $\begin{array}{l}\text { Gene } \times \text { environment } \\
\text { interaction }\end{array}$ & $\begin{array}{l}\text { Assessment of environmental } \\
\text { risk factors (e.g., microbiome), } \\
\text { study of specific subpop- } \\
\text { ulations (e.g., early age of } \\
\text { onset) }\end{array}$ \\
\hline
\end{tabular}

The missing heritability may also be a consequence of confounding factors, such as phenocopies (i.e., a patient falsely attributed a disease phenotype), undetermined environmental triggers (i.e., apparent concordance resulting from a shared environmental trigger), and epigenetic influences (e.g., parental imprinting)

\section{EVOLUTIONARY GENETICS IN HUMANS}

\section{General Concepts and Methods}

Evolutionary or population genetics is another approach that provides invaluable immunological information and involves analysis of the distribution, in human populations, of alleles at loci known or presumed to be involved in host defense and/or self-tolerance, and the comparison of this distribution with that in other species, including primates in particular. If we wish to understand immunological heterogeneity, both between individuals and between populations, we can investigate the way in which natural selection has acted on host genes over time, by determining the current patterns of variability in the general population (individuals not chosen for study on the basis of a particular disease phenotype) (Sabeti et al. 2006; Quintana-Murci et al. 2007; Barreiro and Quintana-Murci 2010; Quintana-Murci and Clark 2013). Contemporary humans are the descendants of people who survived multiple threats, including those posed by microbes (a greater threat than war, predation, and famine) (Cairns 1997). "Natural" conditions have changed, particularly in western countries, but modern medicine, introduced at the start of the 20th century ("yesterday" from an evolutionary standpoint), has not yet had time to affect the pattern of population genetic diversity. If human adaptation to microbial pressure has a genetic basis, it will be engraved in our genomes, so evolutionary genetics can quantify the action of selection on host genes (Sabeti et al. 2006; Nielsen et al. 2007). Numerous studies have searched for the footprints of selection at the GW level and identified immunity-related genes among those most strongly targeted by selection, in its different forms and intensities (Bustamante et al. 2005; Voight et al. 2006; Sabeti et al. 2007; Barreiro et al. 2008; Pickrell et al. 2009; Grossman et al. 2013). Purifying selection removes deleterious alleles from the population, whereas positive and balancing selection favor increases in the population frequency of advantageous variants and the maintenance of polymorphism, respectively (Table 3). Each type of selection leaves a distinctive molecular signature around the genomic region targeted, and these signatures can be detected by various statistical approaches (Nielsen 2005; Sabeti et al. 2006; Nielsen et al. 2007). On the basis of these signatures, population genetics theory can be used to infer the relative biological contributions of different classes of immunity genes to host defense in natura.

\section{Maintaining the Status Quo: Essentiality}

Selection often results in maintenance of the status quo, by eliminating genetic variants with an impact on protein function that may compromise organism fitness. Genes subject to strong purifying selection, for which mutations are highly deleterious for the carrier, generally display a major deficit of amino-acid altering mutations. This is the case, for example, for a number of genes encoding innate immunity molecules, such as endosomal TLRs and most of the NALP members of the NLR family (Barreiro et al. 2009; Wlasiuk and Nachman 2010; Vasseur et al. 2012), 
Table 3. Different forms of natural selection and their relation to immunity and disease

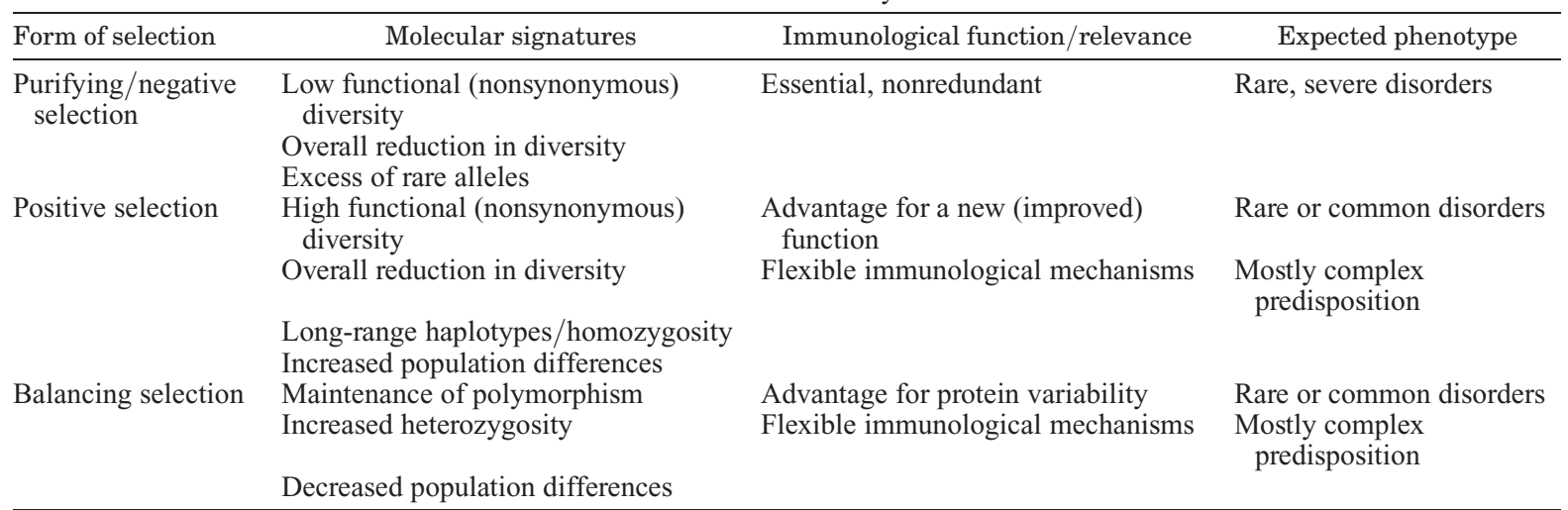

Each form of selection leaves a specific molecular signature around the genomic region targeted, which can be detected by an increasing number of statistical methods (Nielsen et al. 2007, for a thorough review). Depending on the intensity and form of selection in place, population genetics can provide useful information about the function and relative biological relevance of immunity-related genes as well as predict the mode in which these genes may contribute to disease. The expected phenotypes represent the general trends observed, but note that they are not exclusive (e.g., positive selection can also increase the frequency of mutations exerting a protective and almost Mendelian effect against infections) (Quintana-Murci and Barreiro 2010).

adaptors such as MYD88 and TRIF (Nakajima et al. 2008; Fornarino et al. 2011), or effector molecules, such as a subset of IFN- $\alpha / \beta$ and IFN- $\gamma$ (Manry et al. 2011). This attests to the unique, essential nature of the mechanismsimmunological or otherwise-involved. Furthermore, variation in genes evolving under strong purifying selection would be expected to lead to severe, highly penetrant and even Mendelian disorders. This prediction is supported by GW population studies, as genes associated with Mendelian disease are enriched in signs of purifying selection (Bustamante et al. 2005; Barreiro et al. 2008; Blekhman et al. 2008), particularly when the diseasecausing alleles are dominant by haploinsufficiency (e.g., RPSA mutations in patients with congenital asplenia) (Bolze et al. 2013). Clinical genetic studies also support this notion, as rare mutations underlying life-threatening diseases have been found in highly constrained genes and pathways. For example, mutations in the TLR3-TRIF, TIR-MYD88, and IFN- $\gamma$ pathways have been associated with life-threatening infections during childhood: HSV-1 encephalitis (Zhang et al. 2007, 2013; Guo et al. 2011; Sancho-Shimizu et al. 2011), pyogenic bacterial infections (Picard et al. 2003, 2010; Ku et al. 2007; von Bernuth et al. 2008), and MSMD (Jouanguy et al. 1996; Newport et al. 1996; Casanova and Abel 2002; Bogunovic et al. 2012), respectively. Similarly, mutations of the NALP3 and RPSA genes have been associated with severe inflammatory disease (Hoffman et al. 2001; Aganna et al. 2002; Strowig et al. 2012) and invasive bacterial disease due to congenital asplenia (Bolze et al. 2013), respectively.

\section{Relaxing the Constraints: Immunological Redundancy}

Purifying selection acts less strongly on mildly deleterious mutations, which can be tolerated and may even increase in frequency in the population, depending on the extent to which they are deleterious to host survival. Genes evolving under weaker selective constraints (i.e., weak negative selection) tend to be involved in more re- dundant mechanisms than strongly constrained genes (those under strong purifying selection) (Quintana-Murci and Clark 2013). For example, among the innate immunity sensors responsible for detecting nucleic acids, the weaker constraints characterizing the three members of the RIG-I-like receptor (RLR) family than endosomal TLRs suggest that there is some degree of redundancy for RLR-mediated antiviral immunity (Barreiro et al. 2009; Wlasiuk and Nachman 2010; Vasseur et al. 2011). Furthermore, variation in genes evolving under relaxed constraints would be expected to have milder effects on host phenotype. At the GW level, purifying selection tends to be weaker for "complex" disease genes than for "Mendelian" disease genes (Di Rienzo 2006; Kryukov et al. 2007; Blekhman et al. 2008; Alcais et al. 2010). In some cases, the constraint may be relaxed completely, and the population frequency of mutations with an impact on protein function can increase freely under conditions of strict neutrality, demonstrating the highest levels of immunological redundancy. This is the case for genes such as MBL2, TLR5, and TLR10, for which the frequency of loss-of-function mutations is high at population level (up to $25 \%$, depending on the population), indicating that distinct immunological mechanisms may confer sufficient protection against infection in the absence of these genes (Verdu et al. 2006; Walsh et al. 2006; Barreiro et al. 2009; Wlasiuk et al. 2009). In other cases, gene loss may even be advantageous to the host (MacArthur et al. 2012; Quintana-Murci 2012), according to the "less-is-more" hypothesis, as illustrated by the high population frequencies of loss-of-function mutations of genes such as DARC, CASP12, or some leukocyte Ig-like receptor genes (Hamblin et al. 2002; Xue et al. 2006; Hirayasu et al. 2008), owing to their protective effects against infection.

\section{Favoring Advantageous Variation: Improving Gene Function}

The detection of positive and balancing selection makes it possible to define more dynamic immunological 
mechanisms, variations of which have been beneficial to the host over different evolutionary timescales. Recent data indicate that long-term balancing selection (i.e., a heterozygote advantage that has persisted across species) has occurred not only at the well-known HLA locus, but also at other immunity-related loci, such as the membrane glycoprotein, ABO blood group, or TRIM5 genes (Klein et al. 1993; Cagliani et al. 2010; Segurel et al. 2012; Leffler et al. 2013). Humans may also have acquired advantageous variants through admixture with other hominids, such as Neandertals or Denisovans, as reported for some HLA alleles (Abi-Rached et al. 2011). Human populations maintain unexpectedly high levels of genetic diversity at some immunity-related loci, due to the effects of balancing selection (Parham and Moffett 2013). A striking example is provided by Amerindian populations, which, despite presenting the lowest level of GW genetic diversity worldwide, have retained high levels of diversity for the HLA and KIR genes, attesting to the advantage of variation at these loci for survival (Gendzekhadze et al. 2009; Parham et al. 2012). In cases of more recent selection or of selection restricted to specific populations, the advantage conferred depends on more recent environmental variables, which may be pathogen-related. Indeed, several studies have shown that pathogen-driven selection has shaped local adaptation of the HLA, blood group antigen and interleukin genes, and the genes encoding their receptors (Prugnolle et al. 2005; Fumagalli et al. 2009a,b, 2011). Selection can increase the frequency of some mutations exerting a protective, strong, in some cases almost Mendelian effect against various infections (QuintanaMurci and Barreiro 2010). Notable examples are provided by the $\mathrm{HbS}$ heterozygotes in Africa, independent G6PDdeficiency variants worldwide, the DARC null allele in Africa, and the various FUT2 deficiency alleles in different populations (Allison 1954; Tishkoff et al. 2001; Hamblin et al. 2002; Saunders et al. 2002; Ferrer-Admetlla et al. 2009; Louicharoen et al. 2009). Selection can also increase the frequency of alleles associated with complex traits or diseases, such as the TLR1 I602S hyporesponsiveness mutation in Europe (Hawn et al. 2007; Johnson et al. 2007; Barreiro et al. 2009; Pickrell et al. 2009), suggesting that there may be an advantage associated with weak TLR1-mediated responses, or with various mutations of the four type III IFN genes in Europeans and Asians (Manry et al. 2011), some of which have been associated with the clearance of HCV infection (Ge et al. 2009; Thomas et al. 2009; Prokunina-Olsson et al. 2013). The match between the selected variants of some genes and their known associations with phenotypic variation provides proof-of-concept for the predictive value of population genetics, particularly for evaluating the disease implications of other, uncharacterized variants targeted by selection.

\section{Side Effects of Past Selection}

Past selection, leading to higher resistance to infection, may, in some cases, result in maladaptation and immune dysfunction, such as autoimmunity and inflammation.
The introduction of hygiene and medical interventions has decreased the pathogen pressure exerted on modern human societies. In this context, the controversial "hygiene hypothesis" states that a decrease in the diversity of microbes we are exposed to (both pathogens and commensals) has led to an imbalance in the immune response, potentially promoting chronic inflammation (Sironi and Clerici 2010). It has been suggested that the underlying mechanism may involve an imbalance between helper $\mathrm{T}$ cells of the "Th1" and "Th2" classes (Szabo et al. 2003; Pulendran and Artis 2012). Population genetics has provided additional support for this hypothesis, as several immunity-related genes, variants of which confer a higher risk of inflammatory bowel disease, celiac disease, T1D, MS, or psoriasis, have been targeted by positive selection (Fumagalli et al. 2009a; Barreiro and Quintana-Murci 2010; Sironi and Clerici 2010; Raj et al. 2013). The higher frequency of alleles conferring greater susceptibility to some of these diseases in populations exposed to high microbial/viral loads, as documented for risk alleles of IL18RAP, IL18R1, IL23, or IL18R1 for inflammatory bowel disease or celiac disease, suggests that these variants play an otherwise beneficial protective role in host defense (Sironi and Clerici 2010). Perhaps the most straightforward example is that of celiac disease. Population genetic and functional analyses have shown that several celiac disease risk alleles of genes such as $I L 12 A$, ILI8RAP, and SH2B3 have been subjected to positive selection and that individuals carrying these alleles benefit from protection against some infections (Barreiro and Quintana-Murci 2010; Zhernakova et al. 2010; Abadie et al. 2011). Further clinical and epidemiological genetic studies are required, but, overall, population genetic studies support the notion that the current increase in the incidence of autoimmune and inflammatory disorders may be at least partly due to past adaptation, strengthening immune responses to combat infectious agents (Sironi and Clerici 2010).

\section{CONCLUSION}

Human genetic studies make use of experiments of $\mathrm{Na}$ ture. The scale is impressive, with the world population steadily increasing and having already reached seven billion individuals, all of whom are genetically unique and exposed to a tremendously variable and changing environment. The depth is also impressive, as these individuals are constantly "phenotyped" by clinicians and can be studied in much more detail in the course of a study, if required. This approach is particularly powerful in immunology, especially as concerns immunity to infection and self-tolerance, the two pillars of immunology. With only about 20,000 protein-encoding genes, many more isoforms, and about 20,000 RNA-encoding genes, and mutation rate for nucleotide substitution in the germline of $10^{-9}$ (on top of other types of mutation), complete dissection of the function of most, if not all of the genes involved in immunity is feasible. Whereas WES can detect variations in only $1 \%-2 \%$ of the genome, WGS has the potential to detect mutations in the remaining, 
intergenic space, which may possibly enlighten its functions. We will undoubtedly witness a flurry of discoveries of single-gene inborn errors of immunity in the coming years. In genetic epidemiology, studies aiming to increase phenotypic homogeneity will probably identify genetic contributions that are stronger than those usually found in GWASs. Population genetics, which has mostly followed a gene-centered approach, with the examination of genes in isolation, will adopt an interactome approach, trying to determine how multiple genes, each contributing modestly to the study phenotype (benign or disease-related), interact with each other and contribute to phenotypic variation (e.g., the Human Gene Connectome) (Itan et al. 2013). One major challenge will be the integrated analysis of all these different sources of genomic information, carefully taking into account context (tissue)-specific effects (Hawkins et al. 2010; Knight 2013). In this context, the iPSC technology can be used to study almost any human cell type from any patient, including nonhematopoietic cells not otherwise studied in humans (Lafaille et al. 2012; Takahashi and Yamanaka 2013). The study of tissue-specific immunity, which is probably altered in tissue-specific infection or autoimmunity, is particularly appealing. As shown here, human genetics has already taught us a great deal about immunology. We firmly believe that, in the era of NGS and iPSC, human genetics is an exciting frontier that is bound to teach us much more about immunology.

\section{ACKNOWLEDGMENTS}

We thank our past, present, and future trainees for their enthusiasm, and Sophie Cypowyj, Fabien Lafaille, Emmanuelle Jouanguy, Xiao-Fei Kong, Janet Markle, Ruben Martinez Barricarte, Guillaume Vogt, and ShenYing Zhang for their critical reading. The laboratory of J.-L.C. is funded by the Rockefeller University, the National Center for Research Resources, and the National Center for Advancing Sciences at the National Institutes of Health (grant no. 8UL1TR000043), the National Institute of Allergy and Infectious Diseases (grant nos. R01AI088364, R01AI089970, R37AI095983, U01AI088685, P01AI061093), the National Institute of Neurological Disorders and Stroke (grant no. R01NS072381), the March of Dimes, Institut Mérieux, and the St. Giles Foundation. The laboratory of L.A. is funded by grants from the Institut National de la Santé et de la Recherche Médicale (INSERM), the Agence Nationale pour la Recherche (ANR), the Agence Nationale de la Recherche sur le SIDA et les hépatites virales (ANRS), the Fondation pour la Recherche Médicale (FRM), the European Research Council (ERC-2010-AdG-268777), and the French Government's Investissement d'Avenir program, Laboratoire d'Excellence "Integrative Biology of Emerging Infectious Diseases" (grant no. ANR10-LABX-62-IBEID). The laboratory of L.Q.-M. has received funding from the Institut Pasteur, the Centre National de la Recherche Scientifique (CNRS), the French Government's Investissement d'Avenir program, Labora- toire d'Excellence "Integrative Biology of Emerging Infectious Diseases" (grant no. ANR-10-LABX-62IBEID), and from the European Research Council under the European Union's Seventh Framework Programme (FP/2007-2013)/ERC grant agreement no. 281297.

\section{REFERENCES}

Abadie V, Sollid LM, Barreiro LB, Jabri B. 2011. Integration of genetic and immunological insights into a model of celiac disease pathogenesis. Annu Rev Immunol 29: 493-525.

Abi-Rached L, Jobin MJ, Kulkarni S, McWhinnie A, Dalva K, Gragert L, Babrzadeh F, Gharizadeh B, Luo M, Plummer FA, et al. 2011. The shaping of modern human immune systems by multiregional admixture with archaic humans. Science 334: 89-94.

Abramson J, Giraud M, Benoist C, Mathis D. 2010. Aire's partners in the molecular control of immunological tolerance. Cell 140: 123-135.

Aganna E, Martinon F, Hawkins PN, Ross JB, Swan DC, Booth DR, Lachmann HJ, Bybee A, Gaudet R, Woo P, et al. 2002. Association of mutations in the NALP3/CIAS1/PYPAF1 gene with a broad phenotype including recurrent fever, cold sensitivity, sensorineural deafness, and AA amyloidosis. Arthritis Rheum 46: 2445-2452.

Alcais A, Abel L. 2004. Application of genetic epidemiology to dissecting host susceptibility/resistance to infection illustrated with the study of common mycobacterial infections. In Susceptibility to infectious diseases: The importance of host genetics (ed. Bellamy R), pp. 7-44. Cambridge University Press, New York.

Alcais A, Alter A, Antoni G, Orlova M, Van Thuc N, Singh M, Vanderborght PR, Katoch K, Mira MT, Thai VH, et al. 2007. Stepwise replication identifies a low-producing lymphotoxin$\alpha$ allele as a major risk factor for early-onset leprosy. Nat Genet 39: 517-522.

Alcais A, Abel L, Casanova JL. 2009a. Human genetics of infectious diseases. In Human genetics: Problems and approaches (eds. Vogel F, et al.), pp. 403-415. Springer, Berlin.

Alcais A, Abel L, Casanova JL. 2009b. Human genetics of infectious diseases: Between proof of principle and paradigm. $J$ Clin Invest 119: 2506-2514.

Alcais A, Quintana-Murci L, Thaler DS, Schurr E, Abel L, Casanova JL. 2010. Life-threatening infectious diseases of childhood: Single-gene inborn errors of immunity? Ann N Y Acad Sci 1214: 18-33.

Al-Herz W, Bousfiha A, Casanova JL, Chapel H, Conley ME, Cunningham-Rundles C, Etzioni A, Fischer A, Franco JL, Geha RS, et al. 2011. Primary immunodeficiency diseases: An update on the classification from the International Union of Immunological Societies expert committee for primary immunodeficiency. Front Immunol 2: 54.

Allison AC. 1954. Protection afforded by sickle cell trait against subtertian malarian infection. Br Med J 1: 290-294.

Al-Muhsen S, Casanova JL. 2008. The genetic heterogeneity of Mendelian susceptibility to mycobacterial diseases. J Allergy Clin Immunol 122: 1043-1051; quiz 1052-1043.

Ambati J, Atkinson J, Gelfand BD. 2013. Immunology of agerelated macular degeneration. Nat Rev Immunol 13: 438-451.

Anderson MS, Venanzi ES, Klein L, Chen Z, Berzins SP, Turley SJ, von Boehmer H, Bronson R, Dierich A, Benoist C, et al. 2002. Projection of an immunological self shadow within the thymus by the aire protein. Science 298: 1395-1401.

Appleby MW, Ramsdell F. 2008. Scurfy, the Foxp3 locus, and the molecular basis of peripheral tolerance. Curr Top Microbiol Immunol 321: 151-168.

Baghdadi JE, Orlova M, Alter A, Ranque B, Chentoufi M, Lazrak F, Archane MI, Casanova JL, Benslimane A, Schurr E, et al. 2006. An autosomal dominant major gene confers predisposition to pulmonary tuberculosis in adults. $J$ Exp Med 203: $1679-1684$. 
Barreiro LB, Quintana-Murci L. 2010. From evolutionary genetics to human immunology: How selection shapes host defence genes. Nat Rev Genet 11: 17-30.

Barreiro LB, Laval G, Quach H, Patin E, Quintana-Murci L. 2008. Natural selection has driven population differentiation in modern humans. Nat Genet 40: 340-345.

Barreiro LB, Ben-Ali M, Quach H, Laval G, Patin E, Pickrell JK, Bouchier C, Tichit M, Neyrolles O, Gicquel B, et al. 2009. Evolutionary dynamics of human Toll-like receptors and their different contributions to host defense. PLoS Genet 5: e1000562.

Bernard C. 1865. Introduction à l'étude de la médecine expérimentale. Baillière, Paris.

Beutler B, Du X, Xia Y. 2007. Precis on forward genetics in mice. Nat Immunol 8: 659-664.

Bibert S, Roger T, Calandra T, Bochud M, Cerny A, Semmo N, Duong FH, Gerlach T, Malinverni R, Moradpour D, et al. 2013. IL28B expression depends on a novel TT/-G polymorphism which improves HCV clearance prediction. $J$ Exp Med 210: $1109-1116$.

Blackwell JM, Jamieson SE, Burgner D. 2009. HLA and infectious diseases. Clin Microbiol Rev 22: 370-385.

Blekhman R, Man O, Herrmann L, Boyko AR, Indap A, Kosiol C, Bustamante CD, Teshima KM, Przeworski M. 2008. Natural selection on genes that underlie human disease susceptibility. Curr Biol 18: 883-889.

Bogunovic D, Byun M, Durfee LA, Abhyankar A, Sanal O, Mansouri D, Salem S, Radovanovic I, Grant AV, Adimi P, et al. 2012. Mycobacterial disease and impaired IFN- $\gamma$ immunity in humans with inherited ISG15 deficiency. Science 337: 1684-1688.

Bogunovic D, Boisson-Dupuis S, Casanova JL. 2013. ISG15: Leading a double life as a secreted molecule. Exp Mol Med 45: e18.

Boisson B, Laplantine E, Prando C, Giliani S, Israelsson E, Xu Z, Abhyankar A, Israel L, Trevejo-Nunez G, Bogunovic D, et al. 2012. Immunodeficiency, autoinflammation and amylopectinosis in humans with inherited HOIL-1 and LUBAC deficiency. Nat Immunol 13: 1178-1186.

Boisson-Dupuis S, Kong XF, Okada S, Cypowyj S, Puel A, Abel L, Casanova JL. 2012. Inborn errors of human STAT1: Allelic heterogeneity governs the diversity of immunological and infectious phenotypes. Curr Opin Immunol 24: 364-378.

Bolze A, Mahlaoui N, Byun M, Turner B, Trede N, Ellis SR, Abhyankar A, Itan Y, Patin E, Brebner S, et al. 2013. Ribosomal protein SA haploinsufficiency in humans with isolated congenital asplenia. Science 340: 976-978.

Bousfiha AA, Jeddane L, Ailal F, Al Herz W, Conley ME, Cunningham-Rundles C, Etzioni A, Fischer A, Franco JL, Geha RS, et al. 2013a. A phenotypic approach for IUIS PID classification and diagnosis: Guidelines for clinicians at the bedside. J Clin Immunol 33: 1078-1087.

Bousfiha AA, Jeddane L, Ailal F, Benhsaien I, Mahlaoui N, Casanova JL, Abel L. 2013b. Primary immunodeficiency diseases worldwide: More common than generally thought. $J$ Clin Immunol 33: 1-7.

Buckley RH. 2004. Molecular defects in human severe combined immunodeficiency and approaches to immune reconstitution. Annu Rev Immunol 22: 625-655.

Bustamante CD, Fledel-Alon A, Williamson S, Nielsen R, Hubisz MT, Glanowski S, Tanenbaum DM, White TJ, Sninsky JJ, Hernandez RD, et al. 2005. Natural selection on protein-coding genes in the human genome. Nature 437: $1153-$ 1157.

Bustamante J, Arias AA, Vogt G, Picard C, Galicia LB, Prando C, Grant AV, Marchal CC, Hubeau M, Chapgier A, et al 2011. Germline CYBB mutations that selectively affect macrophages in kindreds with X-linked predisposition to tuberculous mycobacterial disease. Nat Immunol 12: 213-221.

Byun M, Ma CS, Akçay A, Pedergnana V, Palendira U, Myoung J, Avery DT, Liu Y, Abhyankar A, Lorenzo L, et al. 2013. OX40 deficiency underlies childhood Kaposi sarcoma. $J$ Exp Med 210: 1743-1759.
Cagliani R, Fumagalli M, Biasin M, Piacentini L, Riva S, Pozzoli U, Bonaglia MC, Bresolin N, Clerici M, Sironi M. 2010. Longterm balancing selection maintains trans-specific polymorphisms in the human TRIM5 gene. Hum Genet 128: 577-588.

Cairns J. 1997. Matters of life and death. Princeton University Press, Princeton, NJ.

Carrington M, Nelson GW, Martin MP, Kissner T, Vlahov D, Goedert JJ, Kaslow R, Buchbinder S, Hoots K, O’Brien SJ. 1999. HLA and HIV-1: Heterozygote advantage and B*35$\mathrm{Cw}^{*} 04$ disadvantage. Science 283: 1748-1752.

Casanova JL, Abel L. 2002. Genetic dissection of immunity to mycobacteria: The human model. Annu Rev Immunol 20: $581-620$

Casanova JL, Abel L. 2004. The human model: A genetic dissection of immunity to infection in natural conditions. Nat Rev Immunol 4: 55-66.

Casanova JL, Abel L. 2005. Inborn errors of immunity to infection: The rule rather than the exception. J Exp Med 202: $197-$ 201

Casanova JL, Abel L. 2007. Primary immunodeficiencies: A field in its infancy. Science 317: 617-619.

Casanova JL, Abel L. 2009. Revisiting Crohn's disease as a primary immunodeficiency of macrophages. J Exp Med 206: $1839-1843$.

Casanova JL, Abel L. 2013. The genetic theory of infectious diseases: A brief history and selected illustrations. Annu Rev Genomics Hum Genet 14: 215-243.

Casanova JL, Abel L, Quintana-Murci L. 2011. Human TLRs and IL-1Rs in host defense: Natural insights from evolutionary, epidemiological, and clinical genetics. Аnпи Rev Immиnol 29: 447-491.

Casanova JL, Conley ME, Notarangelo LD. 2013. Inborn errors of immunity. In Fundamental immunology, 7th ed. (ed. Paul WE), pp. 1235-1266. Lippincott Williams \& Wilkins, Philadelphia.

Casrouge A, Zhang SY, Eidenschenk C, Jouanguy E, Puel A, Yang K, Alcais A, Picard C, Mahfoufi N, Nicolas N, et al. 2006. Herpes simplex virus encephalitis in human UNC-93B deficiency. Science 314: 308-312.

Chaigne-Delalande B, Li FY, O'Connor GM, Lukacs MJ, Jiang P, Zheng L, Shatzer A, Biancalana M, Pittaluga S, Matthews $\mathrm{HF}$, et al. 2013. $\mathrm{Mg}^{2+}$ regulates cytotoxic functions of NK and CD8 T cells in chronic EBV infection through NKG2D. Science 341: 186-191.

Cheng MH, Anderson MS. 2012. Monogenic autoimmunity. Annu Rev Immunol 30: 393-427.

Chi CY, Chu CC, Liu JP, Lin CH, Ho MW, Lo WJ, Lin PC, Chen HJ, Chou CH, Feng JY, et al. 2013. Anti-IFN- $\gamma$ autoantibodies in adults with disseminated nontuberculous mycobacterial infections are associated with HLA-DRB1*16:02 and HLADQB1*05:02 and the reactivation of latent varicella-zoster virus infection. Blood 121: 1357-1366.

Cho JH, Gregersen PK. 2011. Genomics and the multifactorial nature of human autoimmune disease. $N$ Engl $J$ Med 365: $1612-1623$.

Cirulli ET, Goldstein DB. 2010. Uncovering the roles of rare variants in common disease through whole-genome sequencing. Nat Rev Genet 11: 415-425.

Concannon P, Erlich HA, Julier C, Morahan G, Nerup J, Pociot F, Todd JA, Rich SS. 2005. Type 1 diabetes: Evidence for susceptibility loci from four genome-wide linkage scans in 1435 multiplex families. Diabetes 54: 2995-3001.

Conley ME, Dobbs AK, Farmer DM, Kilic S, Paris K, Grigoriadou S, Coustan-Smith E, Howard V, Campana D. 2009. Primary B cell immunodeficiencies: Comparisons and contrasts. Annu Rev Immunol 27: 199-227.

Conley ME, Notarangelo LD, Casanova JL. 2011. Definition of primary immunodeficiency in 2011: A "trialogue" among friends. Ann NY Acad Sci 1238: 1-6.

Consortium (Finnish-German APECED). 1997. An autoimmune disease, APECED, caused by mutations in a novel gene featuring two PHD-type zinc-finger domains. Nat Genet 17: $399-403$. 
Cook MC, Vinuesa CG, Goodnow CC. 2006. ENU-mutagenesis: Insight into immune function and pathology. Curr Opin Immunol 18: 627-633.

Cooper GS, Miller FW, Pandey JP. 1999. The role of genetic factors in autoimmune disease: Implications for environmental research. Environ Health Perspect 107(suppl. 5): $693-$ 700.

Cotsapas C, Voight BF, Rossin E, Lage K, Neale BM, Wallace C, Abecasis GR, Barrett JC, Behrens T, Cho J, et al. 2011. Pervasive sharing of genetic effects in autoimmune disease. PLoS Genet 7: e1002254.

Courtois G, Smahi A, Reichenbach J, Doffinger R, Cancrini C, Bonnet M, Puel A, Chable-Bessia C, Yamaoka S, Feinberg J, et al. 2003. A hypermorphic IкB $\alpha$ mutation is associated with autosomal dominant anhidrotic ectodermal dysplasia and $\mathrm{T}$ cell immunodeficiency. J Clin Invest 112: 1108-1115.

Dalmasso C, Carpentier W, Meyer L, Rouzioux C, Goujard C, Chaix ML, Lambotte O, Avettand-Fenoel V, Le Clerc S, de Senneville LD, et al. 2008. Distinct genetic loci control plasma HIV-RNA and cellular HIV-DNA levels in HIV-1 infection: The ANRS Genome Wide Association 01 study. PLoS One 3: e3907.

Davis MM. 2012. Immunology taught by humans. Sci Transl Med 4: $117 \mathrm{fs} 2$.

de Beaucoudrey L, Samarina A, Bustamante J, Cobat A, Boisson-Dupuis S, Feinberg J, Al-Muhsen S, Janniere L, Rose Y, de Suremain M, et al. 2010. Revisiting human IL-12Rß1 deficiency: A survey of 141 patients from 30 countries. Medicine 89: 381-402.

Derry JM, Ochs HD, Francke U. 1994. Isolation of a novel gene mutated in Wiskott-Aldrich syndrome. Cell 79: following 922.

Devriendt K, Kim AS, Mathijs G, Frints SG, Schwartz M, Van Den Oord JJ, Verhoef GE, Boogaerts MA, Fryns JP, You D, et al. 2001. Constitutively activating mutation in WASP causes X-linked severe congenital neutropenia. Nat Genet 27: 313-317.

Di Rienzo A. 2006. Population genetics models of common diseases. Curr Opin Genet Dev 16: 630-636.

Duggal P, Thio CL, Wojcik GL, Goedert JJ, Mangia A, Latanich R, Kim AY, Lauer GM, Chung RT, Peters MG, et al. 2013. Genome-wide association study of spontaneous resolution of hepatitis $\mathrm{C}$ virus infection: Data from multiple cohorts. Ann Intern Med 158: 235-245.

Edwards AO, Ritter R III, Abel KJ, Manning A, Panhuysen C, Farrer LA. 2005. Complement factor H polymorphism and age-related macular degeneration. Science 308: 421-424.

Emond MJ, Louie T, Emerson J, Zhao W, Mathias RA, Knowles MR, Wright FA, Rieder MJ, Tabor HK, Nickerson DA, et al. 2012. Exome sequencing of extreme phenotypes identifies DCTN4 as a modifier of chronic Pseudomonas aeruginosa infection in cystic fibrosis. Nat Genet 44: 886-889.

Fellay J, Shianna KV, Ge D, Colombo S, Ledergerber B, Weale M, Zhang K, Gumbs C, Castagna A, Cossarizza A, et al. 2007. A whole-genome association study of major determinants for host control of HIV-1. Science 317: 944-947.

Ferrer-Admetlla A, Sikora M, Laayouni H, Esteve A, Roubinet F, Blancher A, Calafell F, Bertranpetit J, Casals F. 2009. A natural history of FUT2 polymorphism in humans. Mol Biol Evol 26: 1993-2003.

Fieschi C, Dupuis S, Catherinot E, Feinberg J, Bustamante J, Breiman A, Altare F, Baretto R, Le Deist F, Kayal S, et al. 2003. Low penetrance, broad resistance, and favorable outcome of interleukin 12 receptor $\beta 1$ deficiency: Medical and immunological implications. J Exp Med 197: 527-535.

Forabosco P, Bouzigon E, Ng MY, Hermanowski J, Fisher SA, Criswell LA, Lewis CM. 2009. Meta-analysis of genomewide linkage studies across autoimmune diseases. Eur $J$ Hum Genet 17: 236-243.

Fornarino S, Laval G, Barreiro LB, Manry J, Vasseur E, Quintana-Murci L. 2011. Evolution of the TIR domain-containing adaptors in humans: Swinging between constraint and adaptation. Mol Biol Evol 28: 3087-3097.
Fumagalli M, Cagliani R, Pozzoli U, Riva S, Comi GP, Menozzi G, Bresolin N, Sironi M. 2009a. Widespread balancing selection and pathogen-driven selection at blood group antigen genes. Genome Res 19: 199-212.

Fumagalli M, Pozzoli U, Cagliani R, Comi GP, Riva S, Clerici M, Bresolin N, Sironi M. 2009b. Parasites represent a major selective force for interleukin genes and shape the genetic predisposition to autoimmune conditions. J Exp Med 206: $1395-1408$.

Fumagalli M, Sironi M, Pozzoli U, Ferrer-Admetlla A, Pattini L, Nielsen R. 2011. Signatures of environmental genetic adaptation pinpoint pathogens as the main selective pressure through human evolution. PLoS Genet 7: e1002355.

Gardner JM, Devoss JJ, Friedman RS, Wong DJ, Tan YX, Zhou X, Johannes KP, Su MA, Chang HY, Krummel MF, et al. 2008. Deletional tolerance mediated by extrathymic Aire-expressing cells. Science 321: 843-847.

Ge D, Fellay J, Thompson AJ, Simon JS, Shianna KV, Urban TJ, Heinzen EL, Qiu P, Bertelsen AH, Muir AJ, et al. 2009. Genetic variation in IL28B predicts hepatitis C treatment-induced viral clearance. Nature 461: 399-401.

Gendzekhadze K, Norman PJ, Abi-Rached L, Graef T, Moesta AK, Layrisse Z, Parham P. 2009. Co-evolution of KIR2DL3 with HLA-C in a human population retaining minimal essential diversity of KIR and HLA class I ligands. Proc Natl Acad Sci 106: $18692-18697$.

Gineau L, Cognet C, Kara N, Lach FP, Dunne J, Veturi U, Picard C, Trouillet C, Eidenschenk C, Aoufouchi S, et al. 2012. Partial MCM4 deficiency in patients with growth retardation, adrenal insufficiency, and natural killer cell deficiency. J Clin Invest 122: 821-832.

Good RA. 1991. Experiments of nature in the development of modern immunology. Immunol Today 12: 283-286.

Goris A, Liston A. 2012. The immunogenetic architecture of autoimmune disease. Cold Spring Harb Perspect Biol 4: a007260.

Goulder PJ, Watkins DI. 2008. Impact of MHC class I diversity on immune control of immunodeficiency virus replication. Nat Rev Immunol 8: 619-630.

Grant AV, El Baghdadi J, Sabri A, El Azbaoui S, Alaoui-Tahiri K, Abderrahmani Rhorfi I, Gharbaoui Y, Abid A, Benkirane M, Raharimanga V, et al. 2013. Age-dependent association between pulmonary tuberculosis and common TOX variants in the 8q12-13 linkage region. Am J Hum Genet 92: 407414.

Grossman SR, Andersen KG, Shlyakhter I, Tabrizi S, Winnicki S, Yen A, Park DJ, Griesemer D, Karlsson EK, Wong SH, et al. 2013. Identifying recent adaptations in large-scale genomic data. Cell 152: 703-713.

Guo Y, Audry M, Ciancanelli M, Alsina L, Azevedo J, Herman M, Anguiano E, Sancho-Shimizu V, Lorenzo L, Pauwels E, et al. 2011. Herpes simplex virus encephalitis in a patient with complete TLR3 deficiency: TLR3 is otherwise redundant in protective immunity. J Exp Med 208: 2083-2098.

Haines JL, Hauser MA, Schmidt S, Scott WK, Olson LM, Gallins P, Spencer KL, Kwan SY, Noureddine M, Gilbert JR, et al. 2005. Complement factor $H$ variant increases the risk of age-related macular degeneration. Science 308: 419-421.

Hamblin MT, Thompson EE, Di Rienzo A. 2002. Complex signatures of natural selection at the Duffy blood group locus. Am J Hum Genet 70: 369-383.

Hawkins RD, Hon GC, Ren B. 2010. Next-generation genomics: An integrative approach. Nat Rev Genet 11: 476-486.

Hawn TR, Misch EA, Dunstan SJ, Thwaites GE, Lan NT, Quy HT, Chau TT, Rodrigues S, Nachman A, Janer M, et al. 2007. A common human TLR1 polymorphism regulates the innate immune response to lipopeptides. Eur J Immunol 37: 22802289.

Hirayasu K, Ohashi J, Tanaka H, Kashiwase K, Ogawa A, Takanashi M, Satake M, Jia GJ, Chimge NO, Sideltseva EW, et al. 2008. Evidence for natural selection on leukocyte immunoglobulin-like receptors for HLA class I in Northeast Asians. Am J Hum Genet 82: 1075-1083. 
Hoffman HM, Mueller JL, Broide DH, Wanderer AA, Kolodner RD. 2001. Mutation of a new gene encoding a putative pyrinlike protein causes familial cold autoinflammatory syndrome and Muckle-Wells syndrome. Nat Genet 29: 301-305.

Hughes CR, Guasti L, Meimaridou E, Chuang CH, Schimenti JC, King PJ, Costigan C, Clark AJ, Metherell LA. 2012. MCM4 mutation causes adrenal failure, short stature, and natural killer cell deficiency in humans. J Clin Invest 122: $814-820$.

Hugot JP, Laurent-Puig P, Gower-Rousseau C, Olson JM, Lee JC, Beaugerie L, Naom I, Dupas JL, Van Gossum A, Orholm M, et al. 1996. Mapping of a susceptibility locus for Crohn's disease on chromosome 16. Nature 379: 821-823.

Hugot JP, Chamaillard M, Zouali H, Lesage S, Cezard JP, Belaiche J, Almer S, Tysk C, O'Morain CA, Gassull M, et al. 2001. Association of NOD2 leucine-rich repeat variants with susceptibility to Crohn's disease. Nature 411: 599-603.

Hunt KA, Mistry V, Bockett NA, Ahmad T, Ban M, Barker JN, Barrett JC, Blackburn H, Brand O, Burren O, et al. 2013. Negligible impact of rare autoimmune-locus coding-region variants on missing heritability. Nature 498: 232-235.

Husebye ES, Anderson MS. 2010. Autoimmune polyendocrine syndromes: Clues to type 1 diabetes pathogenesis. Immunity 32: $479-487$.

Itan Y, Zhang SY, Vogt G, Abhyankar A, Herman M, Nitschke P, Fried D, Quintana-Murci L, Abel L, Casanova JL. 2013. The human gene connectome as a map of short cuts for morbid allele discovery. Proc Natl Acad Sci 110: 5558-5563.

Johnson CM, Lyle EA, Omueti KO, Stepensky VA, Yegin O, Alpsoy E, Hamann L, Schumann RR, Tapping RI. 2007. Cutting edge: A common polymorphism impairs cell surface trafficking and functional responses of TLR1 but protects against leprosy. J Immunol 178: 7520-7524.

Jostins L, Ripke S, Weersma RK, Duerr RH, McGovern DP, Hui KY, Lee JC, Schumm LP, Sharma Y, Anderson CA, et al. 2012. Host-microbe interactions have shaped the genetic architecture of inflammatory bowel disease. Nature 491: 119-124.

Jouanguy E, Altare F, Lamhamedi S, Revy P, Emile JF, Newport M, Levin M, Blanche S, Seboun E, Fischer A, et al. 1996. Interferon- $\gamma$-receptor deficiency in an infant with fatal bacille Calmette-Guerin infection. N Engl J Med 335: 1956-1961.

Jouanguy E, Lamhamedi-Cherradi S, Lammas D, Dorman SE, Fondanèche M-C, Dupuis S, Döffinger R, Altare F, Emile J-F, Girdelstone J, et al. 1999. A human IFNGR1 small deletion hotspot associated with dominant susceptibility to mycobacterial infection. Nat Genet 21: 370-378.

Kamatani Y, Wattanapokayakit S, Ochi H, Kawaguchi T, Takahashi A, Hosono N, Kubo M, Tsunoda T, Kamatani N, Kumada H, et al. 2009. A genome-wide association study identifies variants in the HLA-DP locus associated with chronic hepatitis B in Asians. Nat Genet 41: 591-595.

Kavanagh D, Richards A, Atkinson J. 2008. Complement regulatory genes and hemolytic uremic syndromes. Annu Rev Med 59: $293-309$.

Khoury MJ, Beaty TH, Cohen BH. 1993. Fundamentals of genetic epidemiology. Oxford University Press, New York.

Kiepiela P, Leslie AJ, Honeyborne I, Ramduth D, Thobakgale C, Chetty S, Rathnavalu P, Moore C, Pfafferott KJ, Hilton L, et al. 2004. Dominant influence of HLA-B in mediating the potential co-evolution of HIV and HLA. Nature 432: 769 775

Kisand K, Bøe Wolff AS, Podkrajsek KT, Tserel L, Link M, Kisand KV, Ersvaer E, Perheentupa J, Erichsen MM, Bratanic $\mathrm{N}$, et al. 2010. Chronic mucocutaneous candidiasis in APECED or thymoma patients correlates with autoimmunity to Th17-associated cytokines. J Exp Med 207: 299-308.

Klein J, Satta Y, O'Huigin C, Takahata N. 1993. The molecular descent of the major histocompatibility complex. Annu Rev Immunol 11: 269-295.

Klein RJ, Zeiss C, Chew EY, Tsai JY, Sackler RS, Haynes C, Henning AK, SanGiovanni JP, Mane SM, Mayne ST, et al. 2005. Complement factor $H$ polymorphism in age-related macular degeneration. Science 308: 385-389.
Knight JC. 2013. Genomic modulators of the immune response. Trends Genet 29: 74-83.

Kong XF, Vogt G, Itan Y, Macura-Biegun A, Szaflarska A, Kowalczyk D, Chapgier A, Abhyankar A, Furthner D, Djambas Khayat C, et al. 2013. Haploinsufficiency at the human IFNGR2 locus contributes to mycobacterial disease. Hum Mol Genet 22: 769-781.

Kotlarz D, Zietara N, Uzel G, Weidemann T, Braun CJ, Diestelhorst J, Krawitz PM, Robinson PN, Hecht J, Puchalka J, et al. 2013. Loss-of-function mutations in the IL-21 receptor gene cause a primary immunodeficiency syndrome. $J$ Exp Med 210: 433-443.

Krawczyk M, Reith W. 2006. Regulation of MHC class II expression, a unique regulatory system identified by the study of a primary immunodeficiency disease. Tissue Antigens 67: $183-197$.

Krebs HA. 1975. The August Krogh principle: "For many problems there is an animal on which it can be most conveniently studied". J Exp Zool 194: 221-226.

Krogh A. 1929. The progress of physiology. Science 70: 200 204.

Kryukov GV, Pennacchio LA, Sunyaev SR. 2007. Most rare missense alleles are deleterious in humans: Implications for complex disease and association studies. Am J Hum Genet 80: 727-739.

$\mathrm{Ku}$ CL, von Bernuth H, Picard C, Zhang SY, Chang HH, Yang $\mathrm{K}$, Chrabieh M, Issekutz AC, Cunningham CK, Gallin J, et al. 2007. Selective predisposition to bacterial infections in IRAK-4 deficient children: IRAK-4 dependent TLRs are otherwise redundant in protective immunity. $J$ Exp Med 204: 2407-2422.

Lafaille FG, Pessach IM, Zhang SY, Ciancanelli MJ, Herman M, Abhyankar A, Ying SW, Keros S, Goldstein PA, Mostoslavsky G, et al. 2012. Impaired intrinsic immunity to HSV-1 in human iPSC-derived TLR3-deficient CNS cells. Nature 491: $769-773$

Laird NM, Lange C. 2006. Family-based designs in the age of large-scale gene-association studies. Nat Rev Genet 7: $385-$ 394.

Leffler EM, Gao Z, Pfeifer S, Segurel L, Auton A, Venn O, Bowden R, Bontrop R, Wall JD, Sella G, et al. 2013. Multiple instances of ancient balancing selection shared between humans and chimpanzees. Science 339: 1578-1582.

Leslie A, Matthews PC, Listgarten J, Carlson JM, Kadie C, Ndung'u T, Brander C, Coovadia H, Walker BD, Heckerman D, et al. 2010. Additive contribution of HLA class I alleles in the immune control of HIV-1 infection. J Virol 84: $9879-$ 9888.

Li FY, Chaigne-Delalande B, Kanellopoulou C, Davis JC, Matthews HF, Douek DC, Cohen JI, Uzel G, Su HC, Lenardo MJ. 2011. Second messenger role for $\mathrm{Mg}^{2+}$ revealed by human T-cell immunodeficiency. Nature 475: 471-476.

Liu L, Okada S, Kong XF, Kreins AY, Cypowyj S, Abhyankar A, Toubiana J, Itan Y, Audry M, Nitschke P, et al. 2011. Gain-offunction human STAT1 mutations impair IL-17 immunity and underlie chronic mucocutaneous candidiasis. J Exp Med 208: $1635-1648$.

Louicharoen C, Patin E, Paul R, Nuchprayoon I, Witoonpanich B, Peerapittayamongkol C, Casademont I, Sura T, Laird NM, Singhasivanon P, et al. 2009. Positively selected G6PD-Mahidol mutation reduces Plasmodium vivax density in Southeast Asians. Science 326: 1546-1549.

MacArthur DG, Balasubramanian S, Frankish A, Huang N, Morris J, Walter K, Jostins L, Habegger L, Pickrell JK, Montgomery SB, et al. 2012. A systematic survey of loss-of-function variants in human protein-coding genes. Science 335: $823-828$

Manolio TA, Collins FS, Cox NJ, Goldstein DB, Hindorff LA, Hunter DJ, McCarthy MI, Ramos EM, Cardon LR, Chakravarti A, et al. 2009. Finding the missing heritability of complex diseases. Nature 461: 747-753.

Manry J, Laval G, Patin E, Fornarino S, Itan Y, Fumagalli M, Sironi M, Tichit M, Bouchier C, Casanova JL, et al. 2011. 
Evolutionary genetic dissection of human interferons. $J$ Exp Med 208: 2747-2759.

Martin MP, Carrington M. 2005. Immunogenetics of viral infections. Curr Opin Immunol 17: 510-516.

Masters SL, Simon A, Aksentijevich I, Kastner DL. 2009. Horror autoinflammaticus: The molecular pathophysiology of autoinflammatory disease (*). Annu Rev Immunol 27: 621668.

McQuarrie I. 1944. The experiments of nature and other essays. University of Kansas Press, Lawrence, KS.

Migueles SA, Sabbaghian MS, Shupert WL, Bettinotti MP, Marincola FM, Martino L, Hallahan CW, Selig SM, Schwartz D, Sullivan J, et al. 2000. HLA B*5701 is highly associated with restriction of virus replication in a subgroup of HIVinfected long term nonprogressors. Proc Natl Acad Sci 97: 2709-2714.

Mira MT, Alcais A, Van Thuc N, Thai VH, Huong NT, Ba NN, Verner A, Hudson TJ, Abel L, Schurr E. 2003. Chromosome $6 q 25$ is linked to susceptibility to leprosy in a Vietnamese population. Nat Genet 33: 412-415.

Mira MT, Alcais A, Nguyen VT, Moraes MO, Di Flumeri C, Vu HT, Mai CP, Nguyen TH, Nguyen NB, Pham XK, et al. 2004. Susceptibility to leprosy is associated with PARK2 and PACRG. Nature 427: 636-640.

Moshous D, Callebaut I, de Chasseval R, Corneo B, CavazzanaCalvo M, Le Deist F, Tezcan I, Sanal O, Bertrand Y, Philippe N, et al. 2001. Artemis, a novel DNA double-strand break repair/V(D)J recombination protein, is mutated in human severe combined immune deficiency. Cell 105: 177-186.

Nagamine K, Peterson P, Scott HS, Kudoh J, Minoshima S, Heino M, Krohn KJ, Lalioti MD, Mullis PE, Antonarakis SE, et al. 1997. Positional cloning of the APECED gene. Nat Genet 17: 393-398.

Nakajima T, Ohtani H, Satta Y, Uno Y, Akari H, Ishida T, Kimura A. 2008. Natural selection in the TLR-related genes in the course of primate evolution. Immunogenetics 60: $727-$ 735.

Newport MJ, Huxley CM, Huston S, Hawrylowicz CM, Oostra BA, Williamson R, Levin M. 1996. A mutation in the interferon- $\gamma$-receptor gene and susceptibility to mycobacterial infection. N Engl J Med 335: 1941-1949.

Nielsen R. 2005. Molecular signatures of natural selection. Annu Rev Genet 39: 197-218.

Nielsen R, Hellmann I, Hubisz M, Bustamante C, Clark AG. 2007. Recent and ongoing selection in the human genome. Nat Rev Genet 8: $857-868$.

Noguchi M, Yi H, Rosenblatt HM, Filipovich AH, Adelstein S, Modi WS, McBride OW, Leonard WJ. 1993. Interleukin-2 receptor $\gamma$ chain mutation results in X-linked severe combined immunodeficiency in humans. Cell 73: 147-157.

Notarangelo LD. 2013. Functional T-cell immunodeficiencies (with T cells present). Annu Rev Immunol 31: 195-225.

Notarangelo LD, Gambineri E, Badolato R. 2006. Immunodeficiencies with autoimmune consequences. Adv Immunol 89: $321-370$.

Ogura Y, Bonen DK, Inohara N, Nicolae DL, Chen FF, Ramos R, Britton H, Moran T, Karaliuskas R, Duerr RH, et al. 2001. A frameshift mutation in NOD2 associated with susceptibility to Crohn's disease. Nature 411: 603-606.

Pachlopnik Schmid J, Cote M, Menager MM, Burgess A, Nehme N, Menasche G, Fischer A, de Saint Basile G. 2010. Inherited defects in lymphocyte cytotoxic activity. Immunol Rev 235: $10-23$.

Parham P, Moffett A. 2013. Variable NK cell receptors and their MHC class I ligands in immunity, reproduction and human evolution. Nat Rev Immunol 13: 133-144.

Parham P, Norman PJ, Abi-Rached L, Guethlein LA. 2012. Human-specific evolution of killer cell immunoglobulinlike receptor recognition of major histocompatibility complex class I molecules. Philos Trans R Soc Lond B Biol Sci 367: 800-811.

Pereyra F, Jia X, McLaren PJ, Telenti A, de Bakker PI, Walker BD, Ripke S, Brumme CJ, Pulit SL, Carrington M, et al. 2010.
The major genetic determinants of HIV-1 control affect HLA class I peptide presentation. Science 330: 1551-1557.

Perez de Diego R, Sancho-Shimizu V, Lorenzo L, Puel A, Plancoulaine S, Picard C, Herman M, Cardon A, Durandy A, Bustamante J, et al. 2010. Human TRAF3 adaptor molecule deficiency leads to impaired Toll-like receptor 3 response and susceptibility to herpes simplex encephalitis. Immunity 33: 400-411.

Pessach I, Walter J, Notarangelo L. 2009. Recent advances in primary immunodeficiencies: Identification of novel genetic defects and unanticipated phenotypes. Pediatr Res 65: 3R$10 \mathrm{R}$.

Phillips RE. 2002. Immunology taught by Darwin. Nat Immunol 3: 987-989.

Picard C, Puel A, Bonnet M, Ku CL, Bustamante J, Yang K, Soudais C, Dupuis S, Feinberg J, Fieschi C, et al. 2003. Pyogenic bacterial infections in humans with IRAK-4 deficiency. Science 299: 2076-2079.

Picard C, von Bernuth H, Ghandil P, Chrabieh M, Levy O, Arkwright PD, McDonald D, Geha RS, Takada H, Krause JC, et al. 2010. Clinical features and outcome of patients with IRAK-4 and MyD88 deficiency. Medicine 89: 403-425.

Pickrell JK, Coop G, Novembre J, Kudaravalli S, Li JZ, Absher D, Srinivasan BS, Barsh GS, Myers RM, Feldman MW, et al. 2009. Signals of recent positive selection in a worldwide sample of human populations. Genome Res 19: 826-837.

Prokunina-Olsson L, Muchmore B, Tang W, Pfeiffer RM, Park H, Dickensheets H, Hergott D, Porter-Gill P, Mumy A, Kohaar I, et al. 2013. A variant upstream of IFNL3 (IL28B) creating a new interferon gene IFNL4 is associated with impaired clearance of hepatitis C virus. Nat Genet 45: 164171.

Prugnolle F, Manica A, Charpentier M, Guegan JF, Guernier V, Balloux F. 2005. Pathogen-driven selection and worldwide HLA class I diversity. Curr Biol 15: 1022-1027.

Puck JM, Deschenes SM, Porter JC, Dutra AS, Brown CJ, Willard HF, Henthorn PS. 1993. The interleukin-2 receptor $\gamma$ chain maps to Xq13.1 and is mutated in X-linked severe combined immunodeficiency, SCIDX1. Hum Mol Genet 2: 1099-1104.

Puel A, Casanova JL. 2013. Autoantibodies against cytokines: Back to human genetics. Blood 121: 1246-1247.

Puel A, Ziegler SF, Buckley RH, Leonard WJ. 1998. Defective IL7R expression in $\mathrm{T}-\mathrm{B}^{+} \mathrm{NK}^{+}$severe combined immunodeficiency. Nat Genet 20: 394-397.

Puel A, Doffinger R, Natividad A, Chrabieh M, Barcenas-Morales G, Picard C, Cobat A, Ouachee-Chardin M, Toulon A, Bustamante J, et al. 2010. Autoantibodies against IL-17A, IL$17 \mathrm{~F}$, and IL-22 in patients with chronic mucocutaneous candidiasis and autoimmune polyendocrine syndrome type I. J Exp Med 207: 291-297.

Puel A, Cypowyj S, Bustamante J, Wright JF, Liu L, Lim HK, Migaud M, Israel L, Chrabieh M, Audry M, et al. 2011. Chronic mucocutaneous candidiasis in humans with inborn errors of interleukin-17 immunity. Science 332: 65-68.

Puel A, Cypowyj S, Marodi L, Abel L, Picard C, Casanova JL. 2012. Inborn errors of human IL-17 immunity underlie chronic mucocutaneous candidiasis. Curr Opin Allergy Clin Immunol 12: 616-622.

Pulendran B, Artis D. 2012. New paradigms in type 2 immunity. Science 337: 431-435.

Quintana-Murci L. 2012. Genetics. Gene losses in the human genome. Science 335: 806-807.

Quintana-Murci L, Barreiro LB. 2010. The role played by natural selection on Mendelian traits in humans. Ann N Y Acad Sci 1214: 1-17.

Quintana-Murci L, Clark AG. 2013. Population genetic tools for dissecting innate immunity in humans. Nat Rev Immunol 13: 280-293.

Quintana-Murci L, Alcais A, Abel L, Casanova JL. 2007. Immunology in natura: Clinical, epidemiological and evolutionary genetics of infectious diseases. Nat Immunol 8: $1165-1171$. 
Raj T, Kuchroo M, Replogle JM, Raychaudhuri S, Stranger BE, De Jager PL. 2013. Common risk alleles for inflammatory diseases are targets of recent positive selection. Am J Hum Genet 92: 517-529.

Reith W, Satola S, Sanchez CH, Amaldi I, Lisowska-Grospierre B, Griscelli C, Hadam MR, Mach B. 1988. Congenital immunodeficiency with a regulatory defect in MHC class II gene expression lacks a specific HLA-DR promoter binding protein, RF-X. Cell 53: 897-906.

Royer-Pokora B, Kunkel LM, Monaco AP, Goff SC, Newburger PE, Baehner RL, Cole FS, Curnutte JT, Orkin SH. 1986. Cloning the gene for an inherited human disorder-chronic granulomatous disease - on the basis of its chromosomal location. Nature 322: 32-38.

Sabeti PC, Schaffner SF, Fry B, Lohmueller J, Varilly P, Shamovsky O, Palma A, Mikkelsen TS, Altshuler D, Lander ES. 2006. Positive natural selection in the human lineage. Science 312: $1614-1620$.

Sabeti PC, Varilly P, Fry B, Lohmueller J, Hostetter E, Cotsapas C, Xie X, Byrne EH, McCarroll SA, Gaudet R, et al. 2007. Genome-wide detection and characterization of positive selection in human populations. Nature 449: 913-918.

Sancho-Shimizu V, Perez de Diego R, Lorenzo L, Halwani R, Alangari A, Israelsson E, Fabrega S, Cardon A, Maluenda J, Tatematsu M, et al. 2011. Herpes simplex encephalitis in children with autosomal recessive and dominant TRIF deficiency. J Clin Invest 121: 4889-4902.

Saunders MA, Hammer MF, Nachman MW. 2002. Nucleotide variability at G6pd and the signature of malarial selection in humans. Genetics 162: 1849-1861.

Savitsky K, Bar-Shira A, Gilad S, Rotman G, Ziv Y, Vanagaite L, Tagle DA, Smith S, Uziel T, Sfez S, et al. 1995. A single ataxia telangiectasia gene with a product similar to PI-3 kinase. Science 268: 1749-1753.

Sawcer S, Ban M, Maranian M, Yeo TW, Compston A, Kirby A, Daly MJ, De Jager PL, Walsh E, Lander ES, et al. 2005. A high-density screen for linkage in multiple sclerosis. $\mathrm{Am} \mathrm{J}$ Hum Genet 77: 454-467.

Scalzo AA, Yokoyama WM. 2008. Cmv1 and natural killer cell responses to murine cytomegalovirus infection. Curr Top Microbiol Immunol 321: 101-122.

Segurel L, Thompson EE, Flutre T, Lovstad J, Venkat A, Margulis SW, Moyse J, Ross S, Gamble K, Sella G, et al. 2012. The ABO blood group is a trans-species polymorphism in primates. Proc Natl Acad Sci 109: 18493-18498.

Sironi M, Clerici M. 2010. The hygiene hypothesis: An evolutionary perspective. Microbes Infect 12: 421-427.

Smith AM, Rahman FZ, Hayee BH, Graham SJ, Marks DJB, Sewell GW, Palmer CD, Wilde J, Foxwell BMJ, Gloger IS, et al. 2009. Disordered macrophage cytokine secretion underlies impaired acute inflammation and bacterial clearance in Crohn's disease. J Exp Med 206: 1883-1897.

Strowig T, Henao-Mejia J, Elinav E, Flavell R. 2012. Inflammasomes in health and disease. Nature 481: 278-286.

Suppiah V, Moldovan M, Ahlenstiel G, Berg T, Weltman M, Abate ML, Bassendine M, Spengler U, Dore GJ, Powell E, et al. 2009. IL28B is associated with response to chronic hepatitis $\mathrm{C}$ interferon- $\alpha$ and ribavirin therapy. Nat Genet 41: $1100-1104$

Szabo SJ, Sullivan BM, Peng SL, Glimcher LH. 2003. Molecular mechanisms regulating Th1 immune responses. Annu Rev Immunol 21: 713-758.

Takahashi K, Yamanaka S. 2013. Induced pluripotent stem cells in medicine and biology. Development 140: $2457-$ 2461.

Tanaka Y, Nishida N, Sugiyama M, Kurosaki M, Matsuura K, Sakamoto N, Nakagawa M, Korenaga M, Hino K, Hige S, et al. 2009. Genome-wide association of IL28B with response to pegylated interferon- $\alpha$ and ribavirin therapy for chronic hepatitis C. Nat Genet 41: 1105-1109.

Teahan C, Rowe P, Parker P, Totty N, Segal AW. 1987. The Xlinked chronic granulomatous disease gene codes for the $\beta$ chain of cytochrome b-245. Nature 327: 720-721.
Thomas DL, Thio CL, Martin MP, Qi Y, Ge D, O'Huigin C, Kidd J, Kidd K, Khakoo SI, Alexander G, et al. 2009. Genetic variation in IL28B and spontaneous clearance of hepatitis C virus. Nature 461: 798-801.

Thorsby E, Lie BA. 2005. HLA associated genetic predisposition to autoimmune diseases: Genes involved and possible mechanisms. Transpl Immunol 14: 175-182.

Tishkoff SA, Varkonyi R, Cahinhinan N, Abbes S, Argyropoulos G, Destro-Bisol G, Drousiotou A, Dangerfield B, Lefranc G, Loiselet J, et al. 2001. Haplotype diversity and linkage disequilibrium at human G6PD: Recent origin of alleles that confer malarial resistance. Science 293: 455462.

Trapnell BC, Carey BC, Uchida K, Suzuki T. 2009. Pulmonary alveolar proteinosis, a primary immunodeficiency of impaired GM-CSF stimulation of macrophages. Curr Opin Immunol 21: 514-521.

Tsukada S, Saffran DC, Rawlings DJ, Parolini O, Allen RC, Klisak I, Sparkes RS, Kubagawa H, Mohandas T, Quan S, et al. 1993. Deficient expression of a B cell cytoplasmic tyrosine kinase in human X-linked agammaglobulinemia. Cell 72: $279-290$.

Uchanska-Ziegler B, Loll B, Fabian H, Hee CS, Saenger W, Ziegler A. 2012. HLA class I-associated diseases with a suspected autoimmune etiology: HLA-B27 subtypes as a model system. Eur J Cell Biol 91: 274-286.

Vance RE. 2010. Immunology taught by bacteria. J Clin Immunol 30: 507-511.

Vasseur E, Patin E, Laval G, Pajon S, Fornarino S, Crouau-Roy B, Quintana-Murci L. 2011. The selective footprints of viral pressures at the human RIG-I-like receptor family. Hum Mol Genet 20: $4462-4474$.

Vasseur E, Boniotto M, Patin E, Laval G, Quach H, Manry J, Crouau-Roy B, Quintana-Murci L. 2012. The evolutionary landscape of cytosolic microbial sensors in humans. $\mathrm{Am} J$ Hum Genet 91: 27-37.

Verdu P, Barreiro LB, Patin E, Gessain A, Cassar O, Kidd JR, Kidd KK, Behar DM, Froment A, Heyer E, et al. 2006. Evolutionary insights into the high worldwide prevalence of MBL2 deficiency alleles. Hum Mol Genet 15: 2650 2658.

Vidal SM, Malo D, Marquis JF, Gros P. 2008. Forward genetic dissection of immunity to infection in the mouse. Annu Rev Immunol 26: 81-132.

Visscher PM, Brown MA, McCarthy MI, Yang J. 2012. Five years of GWAS discovery. Am J Hum Genet 90: 7-24.

Voight BF, Cotsapas C. 2012. Human genetics offers an emerging picture of common pathways and mechanisms in autoimmunity. Curr Opin Immunol 24: 552-557.

Voight BF, Kudaravalli S, Wen X, Pritchard JK. 2006. A map of recent positive selection in the human genome. PLoS Biol 4: e72.

von Bernuth $\mathrm{H}$, Picard C, Jin Z, Pankla R, Xiao H, Ku CL, Chrabieh M, Mustapha IB, Ghandil P, Camcioglu Y, et al. 2008. Pyogenic bacterial infections in humans with MyD88 deficiency. Science 321: 691-696.

Walsh EC, Sabeti P, Hutcheson HB, Fry B, Schaffner SF, de Bakker PI, Varilly P, Palma AA, Roy J, Cooper R, et al. 2006. Searching for signals of evolutionary selection in 168 genes related to immune function. Hum Genet 119: 92-102.

Wlasiuk G, Nachman MW. 2010. Adaptation and constraint at Toll-like receptors in primates. Mol Biol Evol 27: 21722186.

Wlasiuk G, Khan S, Switzer WM, Nachman MW. 2009. A history of recurrent positive selection at the toll-like receptor 5 in primates. Mol Biol Evol 26: 937-949.

Xue Y, Daly A, Yngvadottir B, Liu M, Coop G, Kim Y, Sabeti P, Chen Y, Stalker J, Huckle E, et al. 2006. Spread of an inactive form of caspase-12 in humans is due to recent positive selection. Am J Hum Genet 78: 659-670.

Zhang G, Luo J, Bruckel J, Weisman MA, Schumacher HR, Khan MA, Inman RD, Mahowald M, Maksymowych WP, Martin TM, et al. 2004. Genetic studies in familial an- 


\section{CASANOVA ET AL.}

kylosing spondylitis susceptibility. Arthritis Rheum 50: 2246-2254.

Zhang SY, Jouanguy E, Ugolini S, Smahi A, Elain G, Romero P, Segal D, Sancho-Shimizu V, Lorenzo L, Puel A, et al. 2007. TLR3 deficiency in patients with herpes simplex encephalitis. Science 317: 1522-1527.

Zhang F, Liu H, Chen S, Wang C, Zhu C, Zhang L, Chu T, Liu D, Yan X, Liu J. 2009a. Evidence for an association of HLA$\mathrm{DRB}^{*} 15$ and DRB1*09 with leprosy and the impact of DRB1*09 on disease onset in a Chinese Han population. BMC Med Genet 10: 133.

Zhang FR, Huang W, Chen SM, Sun LD, Liu H, Li Y, Cui Y, Yan XX, Yang HT, Yang RD, et al. 2009b. Genomewide association study of leprosy. $N$ Engl J Med 361: 26092618.
Zhang F, Liu H, Chen S, Low H, Sun L, Cui Y, Chu T, Li Y, Fu $\mathrm{X}, \mathrm{Yu} \mathrm{Y}$, et al. 2011. Identification of two new loci at IL23R and RAB32 that influence susceptibility to leprosy. Nat Genet 43: $1247-1251$.

Zhang SY, Herman M, Ciancanelli MJ, Perez de Diego R, Sancho-Shimizu V, Abel L, Casanova JL. 2013. TLR3 immunity to infection in mice and humans. Curr Opin Immunol 25: 1933.

Zhernakova A, Elbers CC, Ferwerda B, Romanos J, Trynka G, Dubois PC, de Kovel CG, Franke L, Oosting M, Barisani D, et al. 2010. Evolutionary and functional analysis of celiac risk loci reveals $\mathrm{SH} 2 \mathrm{~B} 3$ as a protective factor against bacterial infection. Am J Hum Genet 86: 970-977.

Zinkernagel RM. 1996. Immunology taught by viruses. Science 271: $173-178$. 


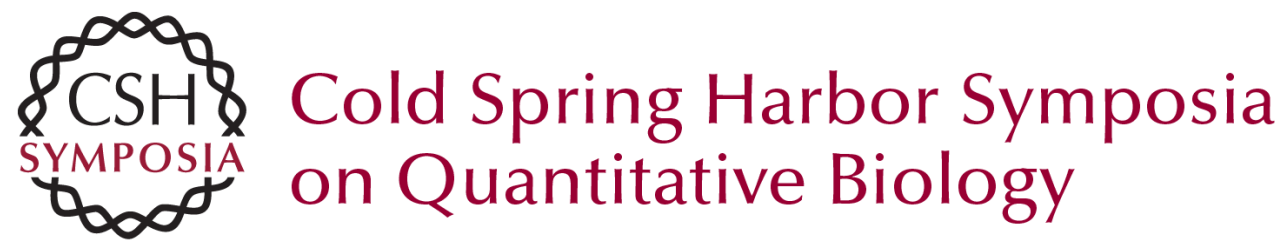

\section{Immunology Taught by Human Genetics}

Jean-Laurent Casanova, Laurent Abel and Lluis Quintana-Murci

Cold Spring Harb Symp Quant Biol 2013 78: 157-172 originally published online October 3, 2013 Access the most recent version at doi:10.1101/sqb.2013.78.019968

References This article cites 205 articles, 60 of which can be accessed free at: http://symposium.cshlp.org/content/78/157.full.html\#ref-list-1

\section{License}

Email Alerting Receive free email alerts when new articles cite this article - sign up in Service the box at the top right corner of the article or click here. 